\title{
A REFORMA DO SETOR ELÉTRICO NO BRASIL, ARGENTINA E MÉXICO: CONTRASTES E PERSPECTIVAS EM DEBATE
}

\author{
Alessandro André Leme
}

\begin{abstract}
RESUMO
A década de 1990 foi marcada por um movimento global de Reformas do Estado, principalmente nos países em desenvolvimento. Nesse processo, as orientações das agências multilaterais fizeram-se mais presentes. $O$ conjunto de reformas liberalizantes transferiu para o setor privado setores até então em mãos do Estado. Dentre esses setores destacamos o caso da infra-estrutura energética. O setor elétrico no Brasil, na Argentina e no México consolidou-se após a II Guerra Mundial, sendo majoritariamente ligado ao Estado. Na década de 1990, nesses três países, esse setor passa por mudanças privatizantes. O quadro de fundo (plano político-econômico) era muito similar entre os países, embora preservassem particularidades econômicas e político-institucionais. A crise de hiperinflação na década de 1980 e as fortes pressões dos organismos multilaterais para a realização de reformas para o mercado (privatização e flexibilização, dentre outros aspectos) levou a mudanças no setor elétrico desses países. Partimos, neste trabalho, de uma abordagem histórico-estrutural e estratégica. Analisamos as reformas no setor elétrico brasileiro em diálogo com as ocorridas na Argentina e no México. Concluímos definindo as principais semelhanças e diferenças entre as políticas liberalizantes do setor elétrico no Brasil, Argentina e México e delimitamos os principais fatores dessas variações, ressaltando a não existência de unicidade histórica na escolhas de estratégias, mas sim composição de estratégias de desenvolvimento decorrentes do embate entre as diversas forças políticas presentes e atuantes num determinado espaço (Estado) com suas variantes nacionais e internacionais.
\end{abstract}

PALAVRAS-CHAVE: reformas do Estado; mercado; reestruturação do setor elétrico; privatização.

\section{INTRODUÇÃO: AS REFORMAS ORIENTA- DAS PARA O MERCADO EM ALGUNS PAÍ- SES EM DESENVOLVIMENTO: BREVE HIS- TÓRIA E CRÍTICA}

O processo político das reformas econômicas na América Latina foi marcado por dois grandes fatores hegemônicos, a saber: a redução do papel do Estado na economia com sua conseqüente transformação e a redefinição das relações entre as economias nacionais e o mercado internacional (nova estratégia de integração na economia mundial globalizada).

O padrão de desenvolvimento econômico promovido pelo Estado em praticamente toda América Latina até meados da década de 1970 começa a ser substituído nos anos 1990 por um novo padrão de desenvolvimento centrado no investimento privado (nacional e internacional), na abertura externa e na valorização do mercado como meio mais adequado ao mundo globalizado. A redefinição das estratégias para o desenvolvimento dá-se como resultado de pressões decorrentes de atores internacionais e nacionais (capital e elites políticas).

As reformas orientadas para o mercado tornam-se parte importante da agenda pública dos governos nacionais. O diagnóstico da insuficiência do modelo nacional-desenvolvimentista acompanha as análises e as condicionalidades que apontam para mudanças liberalizantes da economia.

Desde o final dos anos 1970 já vinham ocorrendo mudanças, que se tornam mais complexas durante a década e 1980 e intensificam-se na década seguinte, quando as reformas orientadas para o mercado passam a ter impacto na organização burocrática do Estado, em especial nos países em desenvolvimento. No plano internacional, as instituições econômicas multilaterais também vão mudando o seu papel, especialmente a partir dos anos 1980 .

Tal fato acaba por fortalecer a necessidade de estudos comparados sobre as experiências de reformas econômicas em países em desenvolvimen- 
to, e, em particular, as reforma engendradas no setor de energia elétrica (por sua característica estrutural e estruturante para as sociedades capitalistas).

Embora não façamos uso a rigor da metodologia de Política Comparada, faremos breves interconexões e contrastes com alguns países latino-americanos, principalmente com o caso brasileiro, argentino e mexicano. Cabe aqui contextualizar o momento histórico, econômico, social e institucional em que as reformas liberalizantes ocorrem nesses países.

A Argentina apresenta sua primeira experiência de liberalização em 1976, após o golpe militar, que pôs fim à segunda experiência peronista. Entre 1976 e 1982, muitas políticas de orientação liberal eliminaram os controles diretos de importação e reduziram as tarifas. A liberação de preços e salários e a redução de restrições às operações cambiais foram outras medidas nessa linha.

Finda a ditadura, o primeiro governo civil, de Raul Alfonsin, impôs controles diretos sobre preços e salários como parte do programa heterodoxo de combate à inflação. Frente às dificuldades enfrentadas na administração do Plano Austral, já em 1986 Alfonsin retoma a política de liberalização comercial, que vai acelerar-se na gestão de seu sucessor, Carlos Menem, em 1991 (BASUALDO, 2002).

Embora nos últimos dois anos do governo Alfonsín tenha havido uma adesão ao discurso das reformas econômicas liberalizantes, isso não se traduziu em medidas mais efetivas de política. Estas passam a ser adotadas a partir de 1989 , com a eleição do Presidente Menem. A forte crise hiperinflacionária e os sucessivos "apagões” elétricos não só levaram à saída de Alfonsín da Presidência antes do término do seu período de governo, como também deram força social e política para que Menem aderisse com toda a força às orientações econômicas voltadas para o mercado.

No caso brasileiro, vai ser durante a segunda metade do governo do Presidente Sarney (19851989), quando o Plano Cruzado fracassa na tentativa de controlar a inflação, que as reformas liberalizantes - abertura comercial, liberalização financeira e privatizações - começariam a entrar de forma mais sistematizada na cena política do país. Porém, será somente a partir do início do governo do Presidente Collor (o primeiro Presi- dente eleito depois fim do regime militar) que efetivamente tais reformas vão ser adotadas. As reformas liberalizantes perpassam o governo do Presidente Itamar Franco (1992-1994) e fortalecem-se nos dois mandatos do Presidente Fernando Henrique Cardoso (1995-2002).

O México, por sua vez, tem no Plano Nacional de Desenvolvimento do Presidente Echevarria (1970-1976) um grande movimento marcado por dois processos: de um lado ocorre uma forte intervenção do Estado na economia e, por outro lado, há inúmeras mobilizações do empresariado contra tal processo.

Outro fato marcante foi a estatização dos bancos, decretada pelo Presidente López Portillo logo após a moratória da dívida externa mexicana em 1982, gerando, com isso, um forte abalo nas relações entre o Estado e o empresariado. Porém, vai ser somente a partir de 1986, nos governos de La Madrid e Salinas Gortari, que começam a ocorrer as reformas liberalizantes no México.

Como complemento e especificidade do caso mexicano, as reformas econômicas internas estão intimamente vinculadas às mudanças promovidas em sua política econômica internacional, expressando-se primeiramente com a adesão do país ao Acordo Geral de Tarifas e Comércio (GATT, da sigla em inglês), em 1986, e com as negociações seguintes de integração regional com o Canadá e os Estados Unidos, formando o Tratado Norte-Americano de Livre Comércio (NAFTA, da sigla em inglês).

Um dos aspectos centrais presentes nesse novo ordenamento das economias dos países em desenvolvimento foi a privatização de diversos setores, entre eles o do setor elétrico. Com isso, a empresa pública, que antes era portadora de uma dupla qualidade, qual seja, a de centro de acumulação de capital e instrumento de política de governo, passa a ser encarada como anomalia perante o liberalismo econômico. O que está em questão sob este novo "olhar" é o ataque frontal à empresa estatal em prol da livre concorrência do capital privado no mercado, que nessa concepção sempre tende ao equilíbrio ${ }^{1}$.

A seguir, vamos apresentar três casos (o brasileiro, o argentino e o mexicano) a fim de ilustrar o

\footnotetext{
${ }^{1}$ Influência, ainda, da lógica do equilíbrio geral walrasiano.
} 
movimento político-econômico e institucional pelo qual os países latino-americanos passaram no final do século XX. As reformas orientadas para o mercado nesses três paises ocorreram nos setores mais atrativos ao capital internacional.

II. AS REFORMAS POLÍTICO-INSTITUCIONAIS REALIZADAS NO SETOR ELÉTRICO BRASILEIRO NA DÉCADA DE 1990.

A geração de energia elétrica no Brasil foi constituindo-se a partir da produção hidrelétrica, consolidando com isso um parque gerador que aproveitou as grandes quantidades de águas interiores (bacias e rios) que o país possui. Num primeiro momento, do final do século XIX até meados da década de 1950, o setor foi conduzido pelo capital privado, especialmente por duas grandes multinacionais (Light e Amforp), ambas também com forte atuação no setor mexicano, nesse mesmo período. A partir da década de 1950, em virtude da forte pressão para o aumento na oferta e na distribuição de eletricidade, o Estado começa a assumir a setor de energia elétrica como estratégico ao país e ao desenvolvimento urbano-industrial. Com isso, vai tomando forma o setor elétrico estatal (que toma a forma de holding, com estrutura federal, estadual e minoritariamente municipal). Esse sistema perdurou até 1995 (i.e.: o governo Fernando Henrique Cardoso), quando são alteradas as leis de concessões e o setor elétrico é aberto ao setor privado via privatizações.

O setor elétrico brasileiro apresentou uma estrutura vertical envolvendo um parque gerador em uma ponta, a transmissão no meio, e na outra ponta, a distribuição. Por meio de uma estrutura hierarquizada (holding) o Estado controlava todas as fases do processo (geração, transmissão e distribuição). Porém, com os novos arranjos político-institucionais da década de 1990 para o setor elétrico, essa estrutura começou a mudar para um modelo de integração horizontal, ou seja, houve uma mudança da estrutura estatal hierarquizada para outra estrutura baseada em empresas privadas e na livre concorrência do mercado de energia elétrica. Essa estrutura horizontal passaria a contar com geradores e distribuidores independentes e transmissão mista. Ao longo das reformas, porém, poucas linhas de transmissão foram privatizadas, sendo a maior parte delas mantida nas mãos do Estado (LEME, 2006).

De forma simplificada, visualiza-se na figura abaixo a nova configuração do setor elétrico brasileiro em um esquema estrutural do setor elétrico.

FIGURA 1 - ESQUEMA DE ESTRUTURAÇÃO DO SETOR ELÉTRICO

Estrutura Vertical

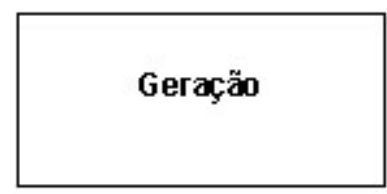

Transmissão

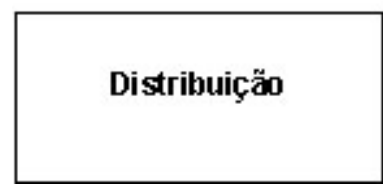

FONTE: Leme, 2000.

\section{Estrutura Horizontal}

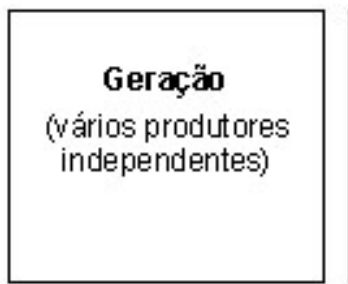

Transmissão

(mista, porém, em

sua maior parcela estatal)
Distribuição

vários

distribuidores

independentes) 
A reforma no setor elétrico brasileiro deuse na década de 1990, juntamente com outras reformas. O processo de reestruturação do setor elétrico acirra-se a partir de 1993, com a promulgação da Lei n. 8 6312. Em 1995, com a promulgação da Lei das Concessões n. 8987 e do Decreto n. 9 074, que regulamentaram o artigo 175 da Constituição ${ }^{3}$, criaram-se condições legais para que os geradores e distribuidores de energia elétrica pudessem competir pelo suprimento dos grandes consumidores de energia elétrica.

O processo de privatização dos setores de geração e transmissão de energia elétrica deviam ser acompanhados por uma regulação do Estado. Porém, a privatização começou a ser implementada antes que o Estado tivesse criado os mecanismos necessários para a nova regulação do setor. A Aneel (Agência Nacional de Energia Elétrica) foi criada somente em 6 de outubro de 1997, por meio da aprovação do Decreto n. 2 335. A Aneel veio exercer a função de órgão regulador em nível federal, substituindo o Dnaee (Departamento Nacional de Águas e Energia Elétrica), reordenando as áreas de negócios do setor em: produção de energia (geração); transporte nas tensões mais altas (transmissão); transporte com o específico objetivo de atendimento a consumidores finais (distribuição); e vendas no varejo, com a função de medir e conquistar os consumidores finais (comercialização).

Na esfera regional, também foram criadas 12 agências reguladoras estaduais, vinculadas à Aneel. Elas visavam atender às especificidades da regulação do setor elétrico dos estados. Foram criadas as seguintes agências: na região Norte, a ARCON (estado do Pará); na região Nordeste, a

2 Essa Lei eliminou o regime tarifário pelo custo de serviço, abrindo espaço para o processo de criação do Produtor Independente de Energia (PIE) e o estabelecimento de regras para fixação de níveis tarifários, além de estabelecer a obrigatoriedade de contratos de suprimento de energia (contendo quantidades e preços) (FERREIRA, 2000).

3 O artigo 175 incumbiu "ao Poder Público, na forma da lei, diretamente ou sob regime de concessão ou permissão, sempre por meio de licitação, a prestação de serviços públicos. - Parágrafo único. A lei disporá sobre: o regime das empresas concessionárias e permissionárias de serviços públicos, o caráter especial de seu contrato e de sua prorrogação, bem como as condições de caducidade, fiscalização e rescisão da concessão ou permissão; os direitos dos usuários; política tarifária; a obrigação de manter serviço adequado".
ARCE (estado do Ceará), ARSEP (estado do Rio Grande do Norte), a ARPE (estado de Pernambuco), a ASES (estado de Sergipe) e a Agerba (estado da Bahia); na região Sudeste, a Agersa (estado do Espírito Santo), a ASEP (estado do Rio de Janeiro) e a CSPE${ }^{4}$ (estado de São Paulo); na região Centro Oeste, a AGER/MT (estado do Mato Grasso) e a AGR (estado de Goiás); e por fim, na região Sul, a Agergs (estado do Rio Grande do Sul).

A aquisição das concessionárias por empresas privadas estrangeiras contou com a ajuda do Banco Nacional de Desenvolvimento (Bndes). Foram tantas as exigências governamentais para a aquisição das concessionárias que nos faz suspeitar do uso indevido do termo "desregulamentação" para caracterizar o que pareceu ser a mudança na forma de atuação do Estado, e não a sua retirada do setor elétrico.

Para implementar a reestruturação do setor elétrico brasileiro, o Ministério de Minas e Energia (MME) contratou, em 1996, um consórcio formado pelas empresas de consultoria internacional Coopers \& Lybrand ${ }^{5}$ e Lathan \& Watkins, e pelas empresas nacionais Main e Engevix (ambas do ramo de engenharia, gerenciamento de projetos e obras). Recorreu também a uma empresa de consultoria na área jurídica, a Ulhôa Canto, Rezende e Guerra, visando colher sugestões para a montagem de um novo desenho para o mercado elétrico brasileiro e de uma nova aparência institucional. Do trabalho dessas empresas surgiu o Projeto de Reestruturação do Setor Elétrico Brasileiro - Reseb (LONGO \& BREMANN, 2002, p. 364). A expectativa do governo era de que os trabalhos da consultoria gerassem sugestões que se valessem de experiências das reformas ocorridas em outros países (principalmente as reformas na Grã-Bretanha), nelas buscando ensinamentos para adaptarem-se ao caso do setor elétrico brasileiro, considerando as suas especificidades. (FERREIRA, 2000).

Dentre as especificidades do caso brasileiro, o governo federal assinalava as seguintes:

a) por ser federativo, o regime brasileiro torna indispensável a divisão dos poderes regulatórios

\footnotetext{
4 Posteriormente transformada em ARSESP - Agência Reguladora de Saneamento e Energia do Estado de São Paulo.

5 Empresa com fortes interesses no Gás da Bolívia.
} 
entre o governo federal e os governos estaduais. Essa divisão traduz-se em uma delicada negociação política numa circunstância em que as empresas elétricas controladas pelos governos estaduais já estão sendo privatizadas (ABRUCIO \& COSTA, 1999, p. 91);

b) o sistema elétrico brasileiro é de base hidráulica, sendo necessário forte coordenação da operação na introdução do processo de concorrência na geração;

c) a rede de transmissão brasileira deveria buscar progressivamente interconectar-se em um sistema nacional;

d) dadas as significativas diferenças regionais e empresariais, alguns mecanismos de compensação regionais precisariam subsistir por um período significativo;

e) a existência de um grande número de empresas controladas por governos estaduais, muitas delas com significativos ativos de transporte e geração, exigiria a convivência de empresas privadas e estaduais no mercado elétrico brasileiro durante um período (REZENDE \& PAULA, 1997, p. 54).

As principais sugestões da Coopers \& Lybrand e demais consultorias que foram aceitas pelo governo brasileiro foram:

a) a criação de um Mercado Atacadista de Eletricidade (MAE) ${ }^{6}$;

b) o estabelecimento de 'contratos iniciais' para criar uma fase de transição para o mercado de energia elétrica competitivo;

c) o desmembramento dos ativos de transmissão e a criação de um Operador Independente do

\footnotetext{
6 O MAE exerce a função de intermediador de todas as transações de compra e venda de energia elétrica dos sistemas elétricos interligados. No Brasil, houve a criação de quatro submercados "spot”, quais sejam: Norte, Nordeste, Sudeste e Sul-Centro-Oeste. Participam do MAE os geradores com capacidade igual ou superior a $50 \mathrm{MW}$, todos os varejistas com carga igual ou superior a $100 \mathrm{GWh}$ e todos os grandes consumidores com demandas acima de $10 \mathrm{MW}$ (TOLMASQUIM \& CAMPOS, 2002). No modelo atual (Governo Lula) o MAE é substituído pela Câmara de Comercialização de Energia Elétrica para atuar nos dois ambientes de contratação (Ambiente de Contratação Regulada - ACR e o Ambiente de Contratação Livre - ACL).
}

Sistema (OIS) para administrar o sistema interligado;

d) a organização das atividades financeiras e de planejamento nesse novo cenário (FERREIRA, 2000).

No campo específico da geração, as recomendações também foram significativas no que tange à transparência e ao acesso livre ao mercado. No conjunto de recomendações destacam-se as seguintes:

a) a desverticalização da geração no que se refere aos ativos federais e estaduais por meio da criação de empresas separadas de geração, as denominadas "gencos" para garantir que o acesso ao mercado de atacado seja livre;

b) a separação horizontal das duas maiores "gencos" federais, Furnas e Chesf, para a criação de duas novas empresas menores a partir de cada uma delas (LONGO \& BREMANN, 2002).

Desse modo, não nos parece que a consultoria ateve-se plenamente à realidade brasileira, na qual o mercado atacadista não iria, ao médio prazo, incluir novos produtos como a energia por fontes térmicas (óleo, gás, carvão e nuclear, como na Inglaterra). Outro equívoco relevante da consultoria foi ter desprezado, em suas análises, o controle das cheias, a irrigação, o abastecimento de água potável, a navegação e o desenvolvimento regional integrado, questões que são vitais para a nova modelagem energética no Brasil (REZENDE \& PAULA, 1997; MEIRELES, 1999).

Tendo em vista as possíveis contradições entre as propostas oriundas da consultoria Coopers \& Lybrand e a realidade do setor elétrico brasileiro, é mister supor que a reestruturação do setor elétrico brasileiro merece um olhar crítico. Sob tal perspectiva, Biondi (1999), Petras (1999), Cano (2000) e Bermam (2002), entre outros, demonstraram que o processo de privatização não foi uma opção de política nacional planejada e discutida publicamente com toda sociedade civil na intenção de consolidar mecanismos democráticos na gestão do setor elétrico brasileiro em sentido estrito e do Estado em geral.

Nesse sentido, as reformas no setor elétrico brasileiro ficaram marcadas por um processo unidirecional que respondeu menos aos interesses dos cidadãos-consumidores de energia elétri- 
ca do país à conveniência das empresas concessionárias - em sua maioria estrangeiras ${ }^{7}$ - que vem explorando, em sentido lato, o mercado nacional de energia elétrica. Tal situação corresponde a uma realidade heterônoma ${ }^{8}$ marcada pela disputa dos interesses das empresas transnacionais do setor em questão.

Há necessidade de analisar a privatização numa perspectiva histórico-estrutural ${ }^{9}$ e estratégica, perante a qual é possível constatar a ocorrência de modificações na relação entre o Estado e o setor privado. Embora as características da privatização sejam a transferência de ativos e de capital, há especificidades na forma como o Estado busca legitimidade social para efetivar tal processo, bem como, também, há especificidades nas razões que o levam a escolher esse processo. (LEME, 2000).

Pela forma com que o setor elétrico brasileiro estruturou-se na história brasileira do último quartel

7 AES (Estados Unidos), Houston (Estados Unidos), CEA (Estados Unidos), Enron (Estados Unidos), Duke-Energy (Estados Unidos), Tractebel (Bélgica), EDF (França), EDP (Portugal), Endesa (Espanha), Iberdrola (Espanha), Endesa (Chile) e Chilectra (Chile) são apenas algumas das empresas transnacionais que participam da distribuição e geração de energia elétrica brasileira.

8 Esse processo de heteronomia do poder político nacional já foi amplamente debatido por Fenandes (1981). Para o autor, tal processo tem historicamente criado situações em que os rumos nacionais são fortemente influenciados por interesses exógenos e tem se atrelado à rede de relações político-econômico tradicionais do Estado brasileiro, formando um compósito deletério ao pleno desenvolvimento social da nação.

9 O conceito de processo histórico-estrutural parece-nos aqui particularmente interessante por permitir, no âmbito metodológico, a necessária fusão entre estrutura e história na análise social. Isso porque, sob tal perspectiva, as estruturas são concebidas como produto da luta social e como resultado da imposição social, sendo, desse modo, analisadas diante de processos. Conforme bem observa Cardoso (1993, p. 97, negritos nossos), “a idéia de que existe uma explicação histórico-estrutural tem a ver com o processo de formação das estruturas e, simultaneamente, com a descoberta das leis de transformação dessas estruturas. Tratase de conceber as estruturas como relações entre os homens que, se bem são determinadas, são também [...] passíveis de mudança, à medida que, na luta social (política, econômica cultural), novas alternativas vão se abrindo à prática histórica. Neste sentido, o objeto da análise não se reifica em atores, mas se dinamiza em conjuntos de relações sociais”. do século XX, sabe-se que não foi por incapacidade do Estado que o setor elétrico começou a voltar para o setor privado a partir de 1995, mas, sim, por um conjunto de pressões exógenas que cobraram, com altos juros, o pagamento da dívida feita pelo Brasil para a construção do modelo do sistema elétrico estatal e eficiente que sobreviveu até o início dos anos 1990.

Furtado (1992), mostra-nos que o programa brasileiro de privatização - e aqui inclui o setor elétrico -, despontou porque a meta era resolver o balanço de pagamentos. Ou seja, a finalidade da privatização apresentava-se inadequada desde a sua proposta de implementação.

As empresas públicas de energia que foram privatizadas surgiram num momento histórico, em que, particularmente o Brasil, estava em fase de substituição das importações, precisando de indústrias e serviços que melhorassem a infra-estrutura. O setor público surge no campo da energia elétrica como uma proposição pragmática, voltada para a promoção do desenvolvimento a partir de alavancagens produtivas e financeiramente custeadas pelo Estado.

Se compararmos o processo de criação de estatais que se deu no passado e o processo de privatização que teve lugar nos anos 1990, podemos afirmar que o primeiro caracterizou-se como um processo determinado no espaço político nacional, enquanto que o segundo caracteriza-se por um processo elitizado e impulsionado pelas forças políticas exógenas (embora pactuados com as elites locais), marcado pela disputa dos países centrais em torno dos mercados emergentes.

Embora a sociedade civil brasileira tenha participado muito pouco do planejamento do setor elétrico nos anos 1950 e 1960, com o processo de privatização nos anos 1990, a participação da sociedade civil, principalmente na esfera político institucional, continuou frágil. As ações do Estado estiveram, na maior parte das vezes, subordinadas às agências multilaterais, às elites supranacionais e elites empresariais nacionais, que não representavam o público que potencialmente iria sofrer os eventuais impactos negativos da privatização.

Assim, se por um lado houve a mobilização das elites junto ao aparelho estatal para dar rápida efetivação ao processo de privatização de partes do setor elétrico, ocorreu, por outro, simultânea 
desmobilização da sociedade civil. Procurou-se mostrar, pelo recurso à mídia, que o processo de privatização não tinha chances de reversão, sendo inúteis as manifestações em contrário.

Quando se verifica o processo de privatização na Inglaterra, na França e nos Estados Unidos, por exemplo, percebe-se a presença de três atores fundamentais no processo, a saber: o Estado, o capital privado e a sociedade civil ${ }^{10}$. No Brasil, todavia, o processo foi marcado por dois atores e um espectador, os primeiros sendo o Estado e o capital privado (internacional ou nacional) e, o espectador, a sociedade civil, caracterizada por possuir pouco peso político e pouco poder de negociação no processo. Embora a sociedade civil tenha apresentado pouco poder político, as dificuldades em cindir as grandes empresas de geração de eletricidade (Chesf e Furnas), associada às duas tentativas fracassadas de privatizar a CESP (geração por meio das usinas no Rio Paraná) e a deflagração da crise em 2001, inviabilizaram que as privatizações efetivassem-se completamente. Ou seja, privatizou-se majoritariamente a distribuição, porém muito pouco se avançou na geração.

O processo de privatização ocorrido incisivamente na década de 1990 ocasionou alterações significativas nos arranjos institucionais do setor, e, ao mesmo tempo redefiniu e/ou criou novos agentes e atores para atuarem no setor. A privatização do setor elétrico brasileiro foi maior na distribuição (federal e estadual), aproximadamente $80 \%$, enquanto na geração (federal e estadual), apenas $20 \%$, aproximadamente, foram privatizadas (LEME, 2005).

De forma sintética, pode-se visualizar na Figura 2 como ficou a concepção do novo modelo para o setor elétrico brasileiro durante o governo de Fernando Henrique Cardoso.

FIGURA 2 - O NOVO MODELO DO SETOR ELÉTRICO

Competição onde possivel
Geração
Agentes específicos
Regulador forte
Operador independente
Planejador indicativo

FONTE: Sauer (2002, p. 146)

Por fim, encontram-se nesse novo arranjo político-institucional, diversos atores vinculados aos debates sobre os Recursos Hídricos. Eles participam dos órgãos setoriais envolvidos com a hidroeletricidade (Comitês de Bacias e

10 Alguns autores já desenvolveram vários trabalhos científicos sobre a privatização em outros países, a saber: Farias Neto, 1994; Velasco Jr., 1997a e 1997b; Petras, 1999; Pires, 1999; dentre outros.
Câmaras Técnicas no Ministério de Minas e Energia e na Aneel), assim como também dialogam para a produção de inventários de bacias (com a CCPE ${ }^{11}$, Aneel e Agência Nacional das Águas - ANA); atuam também na definição de

11 Comitê Coordenador do Planejamento da Expansão dos Sistemas Elétricos, criado pela Portaria n. 150, de 10 de maio de 1999, pelo Ministério das Minas e Energia (MME). 
critérios gerais para a elaboração de Plano Diretor para os reservatórios no Conselho Nacional de Recursos Hídricos (CNRH). Dada a vocação para a geração hidrelétrica no país, o debate em torno da participação intersetorial desses atores (Energia e Água) adquire relevância e centralidade para a tomada de decisões nos rumos do setor elétrico.

Com isso fica evidente que a reflexão e a implementação de políticas no que concerne à reestruturação do setor elétrico brasileiro, passa necessariamente pela compreensão e pela possibilidade histórica de interpretar e explicar o conjunto de relações no qual o setor encontra-se envolvido, ou seja, relacionando-o com a sustentabilidade que envolve de forma sinérgica a energia, a equidade social, o meio ambiente, o emprego e a democracia. Só assim poder-se-ia realizar uma reestruturação, prevendo evitar as grandes disparidades que têm ocorrido tanto nas benesses geradas quanto nos prejuízos assumidos entre os diversos atores sociais, em que os mais desfavorecidos historicamente são os que mais têm sofrido os malefícios (aumentos de tarifas, entre outros aspectos).

Destaca-se que toda essa estrutura e esses atores envolvidos direta ou indiretamente com o setor elétrico brasileiro passaram por um marco político e simbólico muito relevante que foi a crise no setor em 2001'2. Alguns dos reflexos da crise ainda podem ser vistos hoje em dia pela forma com que o governo Lula tem dado respostas e proposto uma nova reestruturação para o setor elétrico brasileiro.

Dentre elas, salienta-se que a energia elétrica tem um papel fundamental e estratégico para a

\footnotetext{
12 A crise do setor elétrico, ou "crise do apagão", conforme ficou conhecida, consistiu em cortes forçados e metas de diminuição de gastos (consumo) de energia elétrica, assim como também na ocorrência de alguns blecautes. Por outro lado, a implantação do racionamento (metas de cosumo definidas por classe - industrial, residencial, entre outras) fez que os impactos negativos fossem menores. Isso porque os investimentos no setor (por ser hidrelétrico) demandam um tempo longo de maturação. Como a opção do governo foi deixar as empresas atrativas ao capital privado, as mesmas (que já vinham estranguladas desde meados da década de 1980) foram proibidas de investir, gerando com isso um situação muito tênue entre o equilibrio da oferta/demanda e a crise, deflagrando-se, em 2001, a crise no setor.
}

sociedade, devendo ser encarada como fator de inclusão social e desenvolvimento econômico ${ }^{13}$. O propósito desse modelo é a formulação de um arranjo institucional que se pretenda estável e duradouro para o setor elétrico brasileiro. As principais questões postas são:

a) promover a melhoria na segurança de suprimento de energia;

b) harmonizar o papel dos diversos agentes e instituições, criando um quadro favorável de investimentos;

c) o pool $^{14}$ como mecanismo de segurança para os consumidores que dependem da energia vendida por distribuidoras;

d) planejamento para a redução dos custos da energia (BRASIL, 2003).

Como principais aspectos em contraponto ao modelo anterior (criado pelo governo de FHC) estão: a restauração do papel do poder Executivo como poder concedente do setor elétrico; a reestruturação do planejamento de médio e longo prazo; o monitoramento, em curto prazo, das condições de atendimento; e o redirecionamento da contratação de energia para longo prazo, compatível com a amortização dos investimentos realizados. Destaca-se também a co-existência de dois ambientes de contratação de energia: um regulado, o Ambiente de Contratação Regulada - ACR, que visa proteger o consumidor cativo, e outro livre, o Ambiente de Contratação Livre - ACL, que visa estimular a iniciativa dos consumidores livres; a instituição de um pool de contratação regulada de energia a ser comprada pelos concessionários de distribuição; a desvinculação do serviço de distribuição de qualquer outra atividade; e a previsão de uma reserva conjuntural para o restabelecimento das condições de equilíbrio entre oferta e demanda (idem).

13 Aqui queremos destacar a importância política e simbólica em encarar o setor como fator de inclusão e desenvolvimento econômico, em vez de vê-lo puramente pela eficiência na gestão e pela competitividade no mercado, como proposto pelo governo anterior. Talvez esse seja um dos principais pontos políticos de diferença entre o governo anterior e o atual no que concerne a visão sobre o setor elétrico brasileiro.

14 Entende-se como o acordo e/ou reunião de empresas ou pessoas para a execução de tarefas; no caso do setor elétrico, o pool seria um dos meios garantidores da entrega (distribuição) de eletricidade aos consumidores finais. 
A nova política energética para o setor elétrico brasileiro tende a redefinir o setor em dois aspectos centrais: o primeiro diz respeito à restauração do papel do poder Executivo como concedente, ou seja, a re-centralização do poder nas mãos do governo e, conseqüentemente a promoção de alterações em toda a estrutura institucional do setor elétrico na sua relação com cada ator/agente do mesmo. Um segundo aspecto refere-se à tentativa de promover uma parceria público/privada na construção de novas hidrelétricas, na intenção de gerar novos investimentos para o setor elétrico, que precisa crescer para dar base ao crescimento econômico e à melhoria da qualidade de vida da população.

III. AS REFORMAS NO SETOR ELÉTRICO ARGENTINO: IMPLANTAÇÃO DAAGENDA LIBERALIZANTE E CRISE NO SETOR

O setor elétrico argentino, assim como o brasileiro, constitui-se a partir da iniciativa privada (capital nacional e internacional), porém, não majoritariamente por fonte hidrelétrica, mas por termelétrica (à óleo e gás). A hidreletricidade na Argentina representa pouco mais de $30 \%$ do setor. Assim como a maioria dos países latino-americanos (entre eles destacamos o caso brasileiro e mexicano), a Argentina começa a estatizar o seu setor elétrico a partir da década de 1950 . A principal motivação para a entrada do Estado no setor foi a garantia de investimentos necessários à rápida industrialização pela qual o país passava. As principais empresas envolvidas nesse processo foram a Água y Energia Eléctrica - AYE, a SEGBA ${ }^{15}$ (concessionária da província de Buenos Aires) e a Hidrono, todas empresas federais.

Desde a redemocratização da Argentina, em 1983, o país vem passando por ciclos de estabilidade e crise na economia. A partir do primeiro governo do Presidente Menem, em 1990, foi implantado no país um novo modelo de crescimento econômico assentado na liberalização comercial, nas reformas econômicas e numa rígida ordem fiscal e monetária.

Os principais mecanismos para a sustentação dessa nova condução econômica foram a reforma estrutural do setor público, as privatizações das companhias do Estado e a re-

15 Ambas as empresas com atuação na geração, distribuição e transmissão de energia. organização de mercados competitivos a fim de promover uma melhor alocação dos recursos. As reformas orientadas para o mercado, dentre elas as privatizações dos setores estratégicos (energia, por exemplo) têm suas bases econômicas e sociais no governo militar no final da década de 1970 e início da década de 1980. Nesse período, a Argentina passou por um processo de crescente endividamento externo, decorrente em grande medida das orientações políticas e econômicas do governo militar. A ditadura militar argentina do período de 1976 a 1983 levou o país a um processo de desindustrialização, combinado a um aumento significativo do capitalismo financeiro. O resultado desse processo foi a redução dos grupos econômicos e uma ampliação da participação do capital internacional (empresas estrangeiras) no cenário nacional (AZPIAZU, 2002; BASUALDO, 2002; ROMERO, 2003).

A redemocratização da Argentina, em 1983, não alterou a centralidade do Estado como instrumento de apropriação do excedente por parte das frações com maior poder econômico e conseqüentemente com maior influência na tomada de decisões do governo e na redefinição do papel do Estado na economia.

Com o processo de concentração econômica no âmbito do Estado após o regime militar, surgiu na Argentina um novo Estado, marcado pelas seguintes características:

a) ampliação do endividamento externo e estatização da dívida externa privada;

b) realização da reforma financeira e a liquidação da dívida interna;

c) os novos regimes de promoção do parque industrial (BASUALDO, 2002, p. 58) ${ }^{16}$.

$\mathrm{O}$ processo de reestruturação econômica e social realizado durante o governo militar (ditatorial) não deixou de gerar um conjunto de contradições, mesmo entre os atores políticos e econômicos que mais se beneficiaram desse processo. Tais contradições começam a tornar-se mais evidentes sob a Argentina democratizada, especial-

16 Para Basualdo (2001) essa seria uma tentativa de retomar as políticas industriais, principalmente pelos prejuízos gerados ao setor durante o regime militar. 
mente a partir de 1988, pouco antes do lançamento do "Plan Primavera17". O Estado não tinha recursos suficientes para garantir as crescentes transferências de recursos aos principais grupos econômicos e ao mesmo tempo cumprir com o pagamento da dívida aos credores estrangeiros (AZPIAZU, 2002; BASUALDO, 2002).

Todavia, alguns grupos econômicos (nacionais e internacionais) souberam aproveitar-se bem dessa rede de benefícios geradas pelo Estado ao capital privado. Dentro desses grupos econômicos mais importantes destacamos os de capital nacional (Astra, Macri, Peres Copanc e Soldati) e aqueles vinculados aos grandes conglomerados estrangeiros, tal como a holding Techint, entre outros (TORRE, 1998; ROMERO, 2003). Esses grupos econômicos vão continuar beneficiando-se do processo de privatização a partir da década de $1990^{18}$. Esse fato demonstra que embora o Estado nacional possua uma "autonomia relativa” para a tomada de decisões sobre os rumos que o país deve adotar como estratégia para o desenvolvimento, a capacidade de pressão e permeabilidade dos interesses do grande capital (nacional e internacional) nos Estados é significativa.

O extenso programa privatista argentino proposto e implantado durante a década de 1990 assentava-se no discurso de melhoramento da qualidade da infra-estrutura física e dos serviços públicos. Alegava-se que a busca de modernização aumentaria a competitividade global da economia.

Um dos setores visados pelas reformas na Argentina foi o setor de energia elétrica. Alegava-se a necessidade de modernizar o setor elétrico e buscar competitividade em esfera global. A privatização do setor elétrico seria a questão central para melhorar a alocação dos recursos e a

\footnotetext{
17 Com a moratória da dívida externa em abril de 1988 e os constantes aumentos na inflação, o governo do Presidente Alfonsin elaborou o Plan Primavera que visava um acordo de aumento de preços e novo regime cambial (com o Estado intermediando a compra e venda de divisas) entre o Estado (governo federal), a União Industrial Argentina e a Câmara Argentina de Comércio. Porém o plano não foi bem sucedido e os operadores de câmbio no mercado não o aceitaram, gerando baixa confiança e resultando em 1989 na suspensão pelo Banco Mundial da ajuda à Argentina e acirrando a crise no país.
}

18 A respeito desse debate, ver Daniel Aspiazu (2002); Eduardo Basualdo (2001); e Daniel Aspiazu e Martín Schorr (2003). eficiência do setor na economia, uma vez que a energia elétrica é fundamental para o desenvolvimento econômico da Argentina, tendo em vista o novo padrão geopolítico global da atualidade.

A seguir, vamos tratar de um pouco da história do setor elétrico na Argentina e de sua relação com o processo de industrialização do país. A principal operadora do setor elétrico argentino, a concessionária Segba, sediada na província da grande Buenos Aires, era uma empresa privada que foi estatizada no final dos anos 1950.

Após a II Guerra Mundial houve, na Argentina, um processo muito semelhante ao ocorrido em outros países latino-americanos, isto é, um avanço gradual do Estado, que começou a assumir as responsabilidades dos investimentos em infra-estrutura no país, visando, com isso, alcançar uma rápida industrialização e modernização do país.

A principal hidroelétrica estatal argentina, com estrutura vertical e integrada, a Águas y Energia Eléctrica (AYE), no seu surgimento, aproveitouse de condições institucionais e de financiamento externo para compor um conjunto de centrais de geração e de distribuição de energia elétrica. Em torno dela construiu-se um sistema interligado de transmissão que atuava na quase totalidade do território argentino ${ }^{19}$.

Mas existe em paralelo, no setor elétrico argentino, um parque térmico que, em 1994, representava aproximadamente $63,5 \%$ da produção de energia do país, distribuído em aproximadamente $57,8 \%$ a óleo e gás, e 5,7\% nuclear. Essa diversificação do setor elétrico argentino deve-se à elevada disponibilidade de reservas de óleo e gás no país. A hidroeletricidade representava em meados dos anos 1990 aproximadamente 36,4\%, operando, em sua maioria, com usinas a fio d'água. Da década de 1950 até o começo da década de 1990 o setor foi estatal. Na primeira metade da década de 1990, com exceção da central nuclear, todo o setor foi privatizado (primeiramente as empresas

\footnotetext{
19 AArgentina não pode comprar energia elétrica de Itaipu em função do acordo Tripartite (1979) entre Brasil, Paraguai e Argentina. O acordo estabeleceu condições para futuros aproveitamentos hidrelétricos da bacia comuns aos três países. Todavia, a usina binacional (Argentina e Paraguai) Yacyretá, a jusante de Itaipu, é responsável por grande parte da energia hidrelétrica no país.
} 
de geração federal e posteriormente as empresas de distribuição das províncias (estados) (ROSA, TOLMASQUIM \& PIRES, 1998).

Na década de 1980, contudo, já vinham ocorrendo várias transformações no setor elétrico argentino: a transferência de ativos da distribuidora AYE para cerca de 17 províncias engendrou um modelo institucional um tanto complexo no país, com uma diversidade envolvendo agentes federais, provinciais e cooperativas municipais. Até a década de 1990, os atores presentes nesse processo representam eminentemente os poderes públicos em suas respectivas instâncias. A partir das privatizações, o setor elétrico vai ser pulverizado entre diversos atores privados (capital nacional e internacional).

O cenário de fundo da década de 1980 na Argentina foi marcado por três processos fundamentais: 1) a transição de um governo autoritário para um governo democrático com a eleição de Raúl Alfonsín (1983-1989); 2) a crise econômica da década de 1980, marcada pela hiperinflação e crescimento da dívida externa; 3) a implantação da agenda neoliberal, a partir de 1989, com o Presidente Carlos Menem, que adota uma política de ajuste fiscal, de abertura financeira e comercial e de implementação de um conjunto de privatizações.

Com o advento das políticas de orientação neoliberal na Argentina a partir da eleição do governo justicialista de Carlos Menem (1989-1999), criaram-se as condições para o processo de reestruturação e privatização de diversos setores da economia do país, do qual o setor elétrico continuou fazendo parte. Os argumentos para justificar as reformas eram: a deterioração financeira das empresas estatais; a queda da qualidade dos serviços e a crise de oferta, provocada pela queda nos investimentos do setor estatal; a existência de corrupção e má administração das empresas públicas; e a falta de know-how frente às tecnologias mais competitivas (idem).

No processo de reestruturação do setor elétrico, a privatização de empresas estatais foi um dos aspectos centrais. As privatizações visaram as empresas de geração, distribuição e transmissão, pulverizadas entre as três esferas federativas (União, províncias e municípios). Antes de implantá-las, o governo efetuou um conjunto de mudanças setoriais que consistiu, em seu ponto central, na fragmentação das empresas federais em diversas unidades de negócios, visando facilitar as vendas e, ao mesmo tempo, tentar evitar a formação de monopólios privados no setor.

A privatização do setor elétrico argentino foi feita num espaço de tempo muito curto, sustentado pelo argumento de que as reformas privatizantes precisariam ocorrer o mais rápido possível porque, só por meio disso, os problemas correntes de racionamento de eletricidade seriam superados. Aqui é bom salientar que, quando Menem assume a Presidência, em 1989, uma das marcas do governo passado (Alfonsin) eram as constantes crises (apagões e racionamentos) no setor elétrico argentino.

Com as privatizações na geração, distribuição e transmissão de energia, houve também a criação de um 'Mercado Electrico Mayorista' (MEM), cujas atribuições seriam promover um ambiente competitivo de energia elétrica. A administração do MEM era feita por uma companhia independente - a Compañia Administradora Del Mercado Mayorista Electrico Sociedad Anônima (Cammesa) -, na qual participaram diversos atores, entre os quais: acionistas (capital privado), o Estado, os geradores, os distribuidores, os grandes consumidores e as empresas de transmissão (BASUALDO, 2002, p. 69).

Outro momento das reformas no setor elétrico argentino foi a criação de um órgão regulador federal denominado Ente Nacional Regulador de la Electricid (ENRE), cujas atribuições eram: definir os valores tarifários do mercado cativo de energia elétrica (consumidores com demanda inferior a um $1 \mathrm{MWh}$ anual); estabelecer pedágio para o setor de transmissão; impedir a concentração do mercado; e estimular o fim de preços ineficientes.

O setor energético argentino é complexo porque envolve simultaneamente o petróleo, o gás e a energia elétrica (térmica ou hídrica). Como em quase todos os países em desenvolvimento, a Argentina começou a realizar um conjunto de reformas no setor energético que iam desde a desregulamentação do setor até a privatização do mesmo. Embora a Argentina já houvesse apresentado indícios de mudanças de orientação liberalizante durante o governo autoritário (militar), seria somente a partir do final dos anos 1980, já sob grande influência das agências multilaterais e principalmente do chamado "Consenso de Washington” que tais mudanças ocorreriam. Como 
boa parte da América Latina nos anos 1980, a Argentina passava nessa década por processos sucessivos de hiperinflação e crise da dívida externa. Com um quadro de instabilidade e crise, a situação de vulnerabilidade do país face às agências multilaterais, únicas financiadoras externas do país, era grande. Esse foi o quadro dentro do qual as reformas liberalizantes ganharam força e foram implementadas nos países latino-americanos, principalmente na Argentina e, em seguida, no Brasil.

Um dos marcos fundamentais do processo de transformação do setor energético argentino consistiu na transformação do setor hidrocarbonífero pelas leis de Emergência Econômica e da Reforma do Estado em 1989, cuja extensão vai até 1993 com a privatização da YPF (Yacimientos Petrolíferos Fiscales - estatal dedicada à exploração, refino e venda de petróleo e seus produtos derivados).

Num primeiro momento, podemos afirmar que o discurso e a prática privatista assentaram-se em bases materiais de um Estado dilacerado em seu aspecto econômico e político-social, cuja necessidade de reformas faziam-se mais que necessárias.

Porém, pouco tempo depois de realizadas as reformas para o mercado, já se poderia verificar que, na prática, a eficiência e a livre concorrência não estavam ocorrendo da forma como se imaginara. Começou a aparecer nos setores privatizados uma forte concentração e centralização do capital, formando, em muitos casos, monopólios e oligopólios setoriais. Esse foi o caso que ocorreu no setor elétrico argentino.

A reestruturação do setor elétrico argentino começa com a Lei n. 23 696, sancionada em 1989, por meio da qual se iniciou um processo de transformação do setor elétrico com a introdução de novos aspectos/conceitos, quais sejam:

a) introdução e promoção da competição e fortalecimento dos mecanismos de mercado para todas as atividades em que fosse possível;

b) criação de regras para facilitar a concorrência de produtores e consumidores, gerando preços baixos, aumento de eficiência e aumento de oferta elétrica; c) separação do Estado das atividades empresariais do setor, cabendo ao Estado a função de regulador;

d) realizar anualmente informes para orientação do setor elétrico;

e) incorporação do setor privado em condições de risco (ARGENTINA, 2002; AZPIAZU, 2003).

Todavia, a estruturação do setor para o mercado e suas respectivas características foi marcada pela Lei n. 24 065, de 1992, regulamentada pelo Decreto n. 1 398/92, que apresentava como pontos centrais os seguintes aspectos:

a) divisão das atividades do setor elétrico: geração, transmissão, distribuição e comercialização;

b) divisão dos consumidores em grandes usuários e usuários finais. Os primeiros constituemse como agentes do mercado elétrico;

c) existência de um mercado $\operatorname{spot}^{20}$ para a compra-venda de energía;

d) os distribuidores poderiam comprar energia no mercado por um preço estabilizado e atualizado trimestralmente;

e) as empresas geradoras poderiam vender energia no mercado por meio de um preço spot horário;

f) a geração necessária para a satisfação da demanda determina-se em função do custo econômico de operação do sistema elétrico;

g) os preços spot horários determinam-se marginalmente com o custo da próxima unidade a ser convocada (ARGENTINA, 2002).

Outros fatores fizeram parte das novas definições do setor elétrico, destacando-se a possibilidade de intercâmbio do MEM (Mercado Electrico Mayorista) com os países vizinhos, abrindo ca-

20 Por mercado spot entende-se a criação de espaços institucionais usados como bolsas de mercadorias referentes aos negócios realizados com pagamentos à vista e pronta-entrega da mercadoria. A entrega é vinculada ao montante de dinheiro correspondente à quantidade de mercadoria negociada. Mercado spot é o oposto de mercado futuro. 
minho para a exportação ou importação de energia por meio de contratos entre as empresas privadas que estivessem adequadas aos requisitos do marco regulatório.

Assim, de um lado, o conjunto de reformas no setor elétrico argentino alterou de forma efetiva sua modelagem e os atores que dele faziam parte. Por outro lado, as reformas também funcionaram como marco político-econômico e estratégico frente à dívida externa, aos novos papéis do Estado e à incorporação da Argentina ao mundo globalizado. Por meio das privatizações foi possível pagar os serviços da dívida externa aos credores por meio da instrumentalização do mecanismo de capitalização de títulos da dívida em transferência dos ativos estatais (período de 19881990). A nova conjuntura de reformas viabilizou novos investimentos das empresas que agora compunham o mercado elétrico (BASUALDO, 2002).

Pode-se afirmar que as privatizações no setor elétrico funcionaram como fator de conciliação entre os atores internos (capital nacional, elites econômicas e políticas) e externos (capital estrangeiro e transnacional) com a administração governamental, ou seja, entre o Estado e os agentes do mercado (nacional e internacional).

Em síntese, a Argentina reuniu condições políticas, econômicas e institucionais fundamentais que explicam o momento em que deu início às reformas orientadas para o mercado. A primeira tentativa de implementação, sem muito êxito, de uma agenda liberal, remonta aos planos econômicos da última ditadura militar, no governo de Martinez de Hoz. Para esse governante, era de fundamental importância a privatização de algumas empresas públicas. Todavia, nesse período não só não se privatizou nenhuma empresa, como também se incorporou, por meio do Banco Central, um conjunto de empresas privadas que haviam quebrado em função da crise iniciada em 1981.

Entre os atores que atuaram politicamente na tentativa de bloquear tais medidas privatistas estavam os parlamentares justicialistas que, com apoio de alguns sindicatos, contribuíram para que as propostas de privatização não se efetivassem.

Pouco depois de assumir o governo, o Presidente Menem, enviou para o Congresso um conjunto de reformas que continha um ambicioso programa de privatizações muito mais audacioso, radical e acelerado do que o proposto pelo governo militar no final da década de 1970 e início de 1980.

A partir da sanção da Lei de Reforma do Estado em agosto de 1989, que orientava o processo de privatização das principais empresas estatais, a Argentina passou a conviver com um novo papel do Estado, principalmente na gestão do setor público. A Lei de Reforma do Estado estabeleceu, entre outras coisas, que as empresas públicas podiam ser privatizadas mediante decretos do poder Executivo, e que os credores externos poderiam capitalizar seus créditos, o que posteriormente também possibilitou a própria capitalização dos títulos da dívida externa pelos capitais estrangeiros e por alguns grupos econômicos locais (nacionais).

A maior parte das privatizações na Argentina ocorreu entre os anos de 1990 e 1994. Isso faz do processo de privatização argentino um dos mais intensos do mundo, só tendo comparação com algumas transformações ocorridas nos países do leste europeu (antes membros do bloco comunista).

Em poucos anos, o governo Menem implantou um radical programa de privatização no país. Muitas empresas estatais foram transferidas ao setor privado, como: a empresa petrolífera; o sistema ferroviário (de carga e transporte de passageiros); a companhia estatal de prestação de serviços de transporte e distribuição de gás natural; as principais empresas estatais de geração, transmissão e distribuição de energia elétrica; a empresa nacional de telecomunicações; a empresa Aerolíneas Argentinas; empresas do setor de siderurgia e petroquímica de propriedade estatal; dos sistemas portuários e dos canais de rádio e TV, entre outros setores.

No setor elétrico, em particular, as três principais empresas (Segba, AYE e Hidronor) atuantes na geração, distribuição e transmissão de eletricidade na Argentina foram desmembradas e privatizadas, dando origem a um setor desverticalizado. A Segba foi dividida em três empresas distribuidoras e cinco empresas geradoras. A AYE foi dividida em 12 empresas geradoras (sendo nove térmicas e três hidrelétricas). A Hidronor foi desmembrada em quatro empresas hidrelétricas. E as linhas de transmissão de ambas as empresas foram reorganizadas e também privatizadas. 
Por outro lado, embora as privatizações no setor elétrico argentino visassem a pulverização das empresas, de forma a garantir a maior e melhor competitividade no setor, as inúmeras e intrincadas operações e cruzamentos acionários presentes nos processo de privatização não só eliminaram a atomização como gradativamente reintroduziram a integração vertical, porém sob gestão do capital privado (nacional e internacional).

Nesse processo de reintegração, três características foram fundamentais: primeiramente, o reagrupamento das empresas geradoras por meio dos cruzamentos acionários. Em segundo lugar, a integração dos segmentos de geração, distribuição e transmissão da principal empresa atuante na grande Buenos Aires. Em terceiro, a diversificação dos investimentos das empresas elétricas em outras atividades energéticas (petróleo e gás natural) (ROSA, TOLMASQUIM \& PIRES, 1998).

As privatizações no setor elétrico argentino vão diferenciar-se das privatizações do caso brasileiro tanto na quantidade de empresas privatizadas como também na intensidade (velocidade e profundidade) em que tais reformas vão ocorrer. Na Argentina, as privatizações dão-se no curto espaço de quatro anos (1990 a 1994).

Esses são apenas alguns aspectos marcantes do processo de reformas orientadas para o mercado, em que a reestruturação do setor elétrico argentino foi fundamental. Uma das decorrências desse processo foi a crise no setor elétrico no país a partir de 2001, acirrando-se em $2003^{21}$ com o embate entre o governo e as empresas privatizadas no que concerne aos reajustes tarifários. Nesse mesmo período, há como cenário de fundo na Argentina uma grave crise econômica marcada pela moratória do país.

21 Nesse ano, ocorreram vários “apagões” de curta duração no município de Buenos Aires. Tal fato levou a dois movimentos: o primeiro de reivindicação da população com a realização de "panelaços” na Avenida 9 de Júlio. O segundo funcionou como instrumento de pressão das empresas privatizadas para reivindicarem aumentos de tarifas (o que acabou por configurar um embate político entre o governo, as empresas privatizadas e suas matrizes, nesse caso em particular com a EDF, estatal francesa com subsidiária na área de concessão de Buenos Aires).

\section{AS REFORMAS DO SETOR ELÉTRICO NO MÉXICO: DEBATES E PERSPECTIVAS}

O setor elétrico mexicano constituiu-se historicamente sustentando-se na base térmica para a geração/produção de energia elétrica. Todavia, também fazem parte do seu parque gerador algumas plantas de outras matrizes (hidroelétricas, carboelétrica, nucleoelétrica, geotermoelétrica e eólica).

A termoeletricidade e a hidroeletricidade são as principais fontes responsáveis pela manutenção do setor elétrico mexicano. As principais empresas de atuação no setor são públicas, a saber: a Comisión Federal de Electricidad (CFE) e a Luz y Fuerza del Centro.

No começo do século XX, a ampliação do setor elétrico mexicano esteve assentada no capital privado estrangeiro, que crescia a cada ano via concessões do Governo Federal. Na segunda década do século XX, a empresa The Mexican Light \& Power Company Ltd. vê, pela primeira vez, um concorrente adentrar o espaço mexicano para a prestação do mesmo serviço. A entrada da The American and Foreign Power Company (Amforp) foi marcada pela instalação de três sistemas interconectados entre o norte do território nacional. E, no ocidente do país, outra empresa estrangeira denominada de Compañía Eléctrica de Chapala instalou-se no país com uma sede em Guadalajara. Essas duas novas empresas começaram a ampliar suas atividades nas respectivas áreas de influência regional.

Até o começo da década de 1930, o setor elétrico mexicano foi comandado pelas três empresas estrangeiras supra mencionadas. Foi somente na década de 1930, com o Presidente Constitucional Substituto, general Abelardo L. Rodriguéz, que se criou a Comisión Federal de Electricidad (CFE), em 20 de janeiro de 1934, por meio de Decreto Lei (sendo regularizada por Lei em 1937, com o Presidente general Lázaro Cárdenas del Rio). Um dos objetivos da CFE era o de ampliar a capacidade geradora do país a fim de sustentar o desenvolvimento econômico.

A década de 1930 ainda marcou o crescente aumento demográfico do México, o que acabou por exigir do país uma rápida resposta por meio da ampliação de muitos dos serviços de utilidade pública do Estado, dentre eles, o da energia elétrica. Nesse período, a Mexican Light \& Power Co. 
foi obrigada a ampliar suas plantas de geração para atender a demanda rapidamente crescente por energia elétrica.

Nos anos de 1940 e 1941, iniciou-se o processo de nacionalização da indústria elétrica mexicana, tal qual já havia proposto a Lei de 1937, que regularizava o setor elétrico e estabelecia a exclusividade do Estado na geração/produção de energia elétrica, seja de origem hidráulica ou térmica. Nessa mesma década, mais precisamente em 1949, o Presidente da República Miguel Alemán emitiu um Decreto que transformava a CFE em um organismo público descentralizado e com personalidade jurídica e patrimonial própria.

Embora desde a década de 1930 houvesse tentativas de nacionalizar o setor elétrico mexicano, somente na década de 1960 o setor elétrico tornase estatal, com a compra e nacionalização da Mexican Light \& Power Co, que passou a chamar-se Luz y Fuerza Motriz. Em 1960, a CFE respondia por $54 \%$ da capacidade instalada no país, enquanto a Mexican Light \& Power (nacionalizada na mesma década) respondia por $25 \%$ e a American of Foreign respondia por $12 \%$. As demais companhias respondiam aproximadamente por 9\% da capacidade instalada (COMISIÓN FEDERAL DE ELECTRICIDAD, 2009).

Além da explosão demográfica ocorrida no México desde os anos 1930, o país vivia um período de desenvolvimento industrial, agrícola e de crescimento das atividades urbanas. Contudo, apesar dos esforços de ampliação do parque gerador de energia elétrica, apenas $44 \%$ da população contava com energia elétrica residencial.

Com a Reforma Constitucional de 1960, durante o governo do Presidente Adolfo Lopez Mateos, foi adicionado, ao Artigo 27 da Constituição, o parágrafo sexto que garantia exclusividade ao Estado na função de planejar e produzir energia no país (GUZMÁN, 1994; TORRE, 1998).

A nacionalização do setor elétrico mexicano foi uma resposta à necessidade de integração do Sistema Elétrico Nacional para atender a crescente demanda por eletricidade no país e acelerar a industrialização no México. Como fator políticoinstitucional de estabilização desse sistema, o Estado mexicano adquiriu as empresas privadas que já não realizavam os investimentos na intensidade requerida e necessária ao desenvolvimento do país.
Os investimentos públicos no setor de infraestrutura energética do México corresponderam a mais de $50 \%$ de todo o dinheiro público investido no país a partir dos anos 1960 (COMISIÓN FEDERAL DE ELECTRICIDAD, 2009). Nas décadas seguintes, o crescimento na oferta de energia elétrica do país foi extraordinário, chegando ao final de 1970 a aproximadamente $17360 \mathrm{MW}$ e, em 1991, à capacidade instalada de 26797 MW (idem; GUZMÁN, 1994).

O processo de integração dos sistemas de transmissão, iniciado em 1962, partia do Sistema de Operación Noroeste e do Sistema de Operación Nordeste. Em meados de 1967, já se havia concluído a integração dos Sistemas de Operación Norte, Oriental, Occidental e Central, de modo que, na década de 1970, todo o sistema elétrico mexicano estava integrado. Restavam apenas os sistemas das penínsulas da Baja California e da Yucatán (que só foram integradas ao sistema nacional mexicano em 1990) (TORRE, 1998; ARAGÓN, 2003).

O México, assim como outros países da América Latina, passou pela década de 1980 com constantes e variados programas de estabilização monetária e ajustes estruturais, principalmente a partir da crise do endividamento externo de 1982. Um dos aspectos propostos pelas agências multilaterais no período do ajuste estrutural foram as privatizações de empresas estatais em diversos setores: industrial, financeiro, agropecuário, infraestrutural e de comunicação. As políticas privilegiadas por essas agências focavam a proposição de cortes nos gastos sociais e a privatização dos serviços públicos, num movimento que pretendia transferir as responsabilidades do Estado para as empresas privadas. Pretendia-se mudar a estratégia estatal desenvolvimentista para um modelo de liberalização para o mercado.

Todavia, antes mesmo de entrarmos nos embates propriamente ditos sobre a reestruturação do setor elétrico mexicano, faz-se necessário uma apresentação, ainda que sucinta, da constituição do setor no México, envolvendo a sua principal matriz de geração e respectiva importância desta para o desenvolvimento do país.

Em 1937, o Presidente mexicano Lázaro Cárdenas criou a Comisión Federal de Electricidad (CFE) cuja atribuição principal era a de dirigir/ coordenar um sistema nacional de geração, transmissão e distribuição de energia elétrica (idem; ALONSO, 2003). 
Não havia a intenção, na ocasião, de obter lucro com o setor elétrico, mas, sim, adquirir a energia com o menor custo e o maior rendimento possível. Os principais pontos da Lei de 1937 centravam esforços no planejamento e organização do sistema nacional de eletrificação. Outro fator importante, constituído por Cárdenas nesse processo, foi a criação de um corpo consultivo composto dos seguintes atores: “[...] um representante de los gobiernos estatales, uno de los gobiernos Del Distrito y Territórios Federales, uno de la Secretaría de Agricultura y Fomento, tres de los consumidore, a saber: agricultores, industriales y oeganizaciones de consumidores y uno de las empresas generadoras de energia eléctrica [...]" (MARTÍNEZ, 2003, p. 11-12).

Por razões analíticas, podemos dividir a história do setor elétrico mexicano em quatro grandes movimentos, a saber: primeiramente, o período de aproximadamente 1937 a 1960, marcado pela co-existência da CFE com as empresas privadas estrangeiras; um segundo período, de 1960 a 1983, marcado pela consolidação e expansão do setor elétrico mexicano; um terceiro período, de crise político-institucional e econômica no setor, a partir de 1983 até meados de 1994, com o agravamento da dívida externa; e, por fim, um quarto período, marcado pelo governo de Carlos Salinas, iniciado em 1994 e com forte empenho para privatizar o setor elétrico mexicano.

O primeiro período (1937-1960) tem como principal fator de reflexão e análise a entrada do Estado no setor para promoção e coordenação do desenvolvimento econômico do país, por meio da chamada de responsabilidades para si na condução dos investimentos e da centralidade da indústria elétrica para o país. Todavia, embora o Estado tenha feito tal movimento, ainda co-existiu no sistema elétrico a participação das empresas privadas estrangeiras, que durante o governo do Presidente López Mateos foram compradas e incorporadas ao Estado. Mediante tal incorporação, o Congresso Nacional considerou tais empresas nacionalizadas e ainda incorporou à Constituição o Artigo 27, que se constituía pelas seguintes proposições: “corresponde exclusivamente a la Nación generar, conducir, transformar, distribuir y abastecer energía eléctrica que tenga por objeto la prestación de servicio público. En esta materia no se ortogarán concesiones de servicio a los particulares y la Nación aprovechará los bienes y re- cursos naturales que se requieren para dicho fin." (idem, p. 12).

O propósito do poder Executivo e do Legislativo mexicano, na ocasião, foi o de propor um serviço público moderno e eficiente, cuja capacidade de financiamento ficasse sob responsabilidade do próprio Estado. Ao tomar tais medidas políticas, o governo mexicano, por um lado, garantia a exclusividade e centralidade estatais na gestão dos recursos hídricos para a geração de energia hidroelétrica e, por outro, estabelecia a possibilidade de intervenção do Estado na economia, além de sua própria responsabilidade de ser um agente institucional da promoção do desenvolvimento (ALONSO, 2003).

Uma das causas da mudança estrutural da propriedade e da gestão do setor elétrico mexicano adveio do descompasso entre o monopólio privado estrangeiro e o projeto de desenvolvimento nacional, fato evidenciado pelo desequilíbrio entre oferta e demanda de energia e tarifas elevadas da parte das empresas estrangeiras concessionárias.

Com esse processo de nacionalização da indústria elétrica mexicana surgiu a necessidade de integração energética por meio de um sistema elétrico nacional e da extensão e ampliação da cobertura elétrica.

O financiamento do setor elétrico durante esse primeiro período (1937-1960) foi predominantemente governamental, enquanto que o momento anterior (1879-1936) havia sido marcado por investimentos privados estrangeiros, principalmente de empresas dos Estados Unidos e da Inglaterra. Com o fim da II Guerra Mundial, em 1946, iniciaram-se fortes investimentos, decorrentes de créditos do Banco Mundial e do Eximbank. Já em 1950, a capacidade de geração havia duplicado e os recursos financeiros para a realização de tal feito provinham do governo federal, com $52 \%$ dos investimentos, dos créditos internacionais, com $30 \%$, enquanto as companhias privadas responderam por apenas 18\% dos investimentos, (idem; GUZMÁN, 1994).

Vários estudos e discursos políticos no México da década de 1950 salientaram a importância do fortalecimento e expansão do setor elétrico para o desenvolvimento econômico do país (REVUELTAS, 1993). Dentre os estudos, destacou-se o trabalho de Raul Ortiz Mena, Victor 
Urquidi, Albert Waterston e Jonas Haralz, intitulado "El desarrollo econômico de México y su capacidad para absorber capital del exterior”, cujos aspectos mais relevantes eram: "salvo em la minera em todos los ramos de la economía se registraron fuertes incrementos... este adelanto no se hizo a expensas de la producción agrícola que aumentó de manera considerable... es más sin el aumento de las exportaciones agrícolas, las importaciones de bienes de capital habrían sido menores y la industrialización no habría podido progresar con tanta rapidez. Al mismo tiempo que la industria y la agricultura crecían la industria petrolera, la energia eléctrica y las carreteras" (MARTÍNEZ, 2003, p. 37).

O segundo período (1960-1983) caracterizouse pela consolidação, pela interconexão e unificação da indústria de eletricidade no México. Nesse período, um marco político institucional importante para o setor foi a criação, em 1975, da Lei do Serviço Público de Energia Elétrica, que ratificava o caráter de serviço público da indústria de energia elétrica e estabelecia novas atribuições e responsabilidades à CFE como organismo público descentralizado, com personalidade jurídica e patrimônio próprio.

Por meio da descentralização, foram transferidas para órgãos especializados atribuições que antes estavam sob responsabilidade do governo central. Afirmava-se o caráter de prestação do serviço visando a satisfação da coletividade, devendo ser os serviços regulares, contínuos e uniformes no tempo. Com a Lei do Serviço Público de Energia Elétrica, estabeleceram-se duas grandes fases para o setor, quais sejam:

a) o planejamento do sistema elétrico nacional;

b) a realização de todas as obras requeridas para o setor, assim como a operação e manutenção do sistema elétrico nacional (ALONSO, 2003, p. 26).

Outro fator presente na Lei do Serviço Público de Energia Elétrica e de fundamental importância refere-se à exclusividade do governo federal na condução das empresas prestadoras de serviços públicos de energia elétrica. Para isso, "el Estado contará com los organismos y empresas que requiera para el eficaz manejo de las áreas estratégicas a su cargo" (MARTÍNEZ, 2003, p. 13).
Um dos resultados decorrentes das atribuições legais do CFE na gestão e planejamento do setor elétrico mexicano foi o de promover o desenvolvimento do setor industrial influindo no desenvolvimento do país. Todavia, a partir dos governos de orientação neoliberal22, a crença no papel central do Estado na infra-estrutura e como promotor do desenvolvimento econômico começa a perder espaço.

O terceiro período (1983-1994) foi marcado por uma crise aguda na economia nacional e pela crise da dívida externa (movimento similar à maioria dos países da América Latina na década de 1980). As reformas de cunho neoliberal de um lado, e a Lei do Serviço Público de Energia Elétrica por outro, acabaram por reduzir a expansão do setor elétrico mexicano (REVUELTAS, 1993).

Como resposta a tal processo, o governo de Miguel de la Madrid (1982-1988) orientou-se para tentar reabilitar o setor por meio de uma reforma que apresentou os seguintes aspectos: "se incrementaron sustancialmente las tarifas, se limitó el endeudamiento al 50 \% del programa de inversiones, y se financió el resto con recursos propios y transferencias del gobierno federal... se dispuso la reestructuración de su deuda y la asunción de sus obligaciones en dólares, con instituciones de crédito condicionadas al cumplimiento de compromisos en materia de productividad y eficiencia" (MARTÍNEZ, 2003, p. 13).

O que se verifica com Madrid na Presidência é a implementação de medidas econômicas voltadas para o mercado, tendo na privatização da infraestrutura um elemento central. Tais políticas econômicas vão ser aprofundadas pelo governo seguinte, de Carlos Salinas de Gortari (1988-1994). A abertura e desregulamentação da economia mexicana ocorreram ainda em meados da década de 1980, enquanto que as privatizações de empresas de grande porte só vão ocorrer na década seguinte (ALONSO, 2003, p. 85).

Pode-se afirmar que desde a moratória do México, em 1982, houve pressões externas, principalmente dos Estados Unidos e dos organismos

22 Alguns autores preferem utilizar o termo "neoconservadores" em vez de "neoliberais", por acharem que o primeiro conceito seria mais fidedigno com a realidade histórica do capital. Destacamos David Harvey (2004). 
multilaterais de crédito, para que o México realizasse as reformas necessárias no setor elétrico, tais como a desregulamentação e privatização do setor. Todavia, as tentativas de reestruturar o setor elétrico sempre esbarravam na Constituição, que garantia e definia como competência exclusiva do Estado a prestação dos serviços públicos de energia. Quando o país tornou-se signatário do Nafta em 1994, as pressões aumentaram sensivelmente.

Uma primeira estratégia do governo para enfrentar os impedimentos constitucionais consistiu em retirar da esfera dos serviços públicos um conjunto de atividades do setor de energia, podendo assim passá-las ao setor privado, mediante outorga da CFE. Mediante tal estratégia, a partir de 1992 deixaram de existir barreiras à entrada de capital privado para participar do setor elétrico nas atividades de geração como produtores independentes, na autoprodução, co-geração e pequena produção.

Em meio à crise de financiamento do setor elétrico, que se agravava desde os anos 1980, chegam ao governo, nos anos 1990, políticos de orientação neoliberal como Carlos Salinas e Ernesto Zedillo. Sem poder dar uma resposta efetiva e eficaz ao problema de investimentos de novos recursos para geração e distribuição de energia elétrica, eles deram os primeiros passos para transferir a parte mais rentável do setor energético às empresas privadas de capital estrangeiro, as chamadas transnacionais do setor elétrico.

O quarto período (a partir de 1994) foi marcado pela "obsessão" privatista do governo Carlos Salinas que, atuando por meio da Secretaria da Fazenda e Crédito Público, propôs a incorporação das recomendações do Consenso de Washington: abertura comercial, redução do papel do setor público na economia por meio da privatização dos setores de infra-estrutura e desregulamentação financeira (REVUELTAS, 1993). A despeito das medidas privatizantes da década de 1990, o crescimento anual da geração de energia elétrica no período de 1990-1997 foi de apenas 1,3\%

Todavia, dadas as condições políticoinstitucionais do país, as privatizações no México só poderiam ocorrer de forma paulatina, tal qual já vinha ocorrendo desde 1992, quando se autorizou a geração privada de energia elétrica, visando sempre a auto-geração para o auto-abastecimento, co-geração e produção independente. A políti- ca energética mexicana envolvia a necessidade de reformas constitucionais e a articulação do governo central com as redes de poder local e nacional (interesses do capital nacional, pressões sindicais e de outros setores da sociedade civil organizada).

Ainda havia como fator de pressão exógeno o Consenso de Washington. Uma das instituições formadoras do Consenso, o Banco Mundial, por meio da Estratégia de Assistência ao País (EAP) propôs, em meados dos anos 1990, a privatizações da indústria elétrica nacional (ALONSO, 2003; GUZMÁN, 2003). As recomendações de privatizações no setor elétrico mexicano, oriundas do Banco Mundial, por meio do EAP de 1998, consideravam como primordial e central as privatizações no setor elétrico como condição específica para a ajuda econômica internacional e ao apoio garantido pelo próprio Banco Mundial (TORRE, 1998). Embora tais proposições privatistas tenham sido derrotadas por uma ampla oposição social e sindical, o Presidente Vicente Fox, ainda que internamente reiterasse que a indústria elétrica não devesse ser privatizada, realizou diversas investidas no cenário internacional para oferecer aos investidores estrangeiros a possibilidade de investirem no setor elétrico mexicano.

As experiências de privatização do setor elétrico no Brasil e na Argentina, por exemplo, haviam mostrado que um dos resultados da privatização do setor fora o aumento das tarifas, o comprometimento dos direitos trabalhistas e, principalmente, a redução do controle do Estado sobre um setor tão estratégico para os países em desenvolvimento.

A seguir, vamos apresentar a estrutura do setor elétrico mexicano no que concerne às suas bases físicas e aos órgãos de regulação.

O setor elétrico mexicano hoje é composto por aproximadamente $27 \%$ de geração hidroelétrica, $60 \%$ de termoelétricas (baseadas a óleo combustível - maior parcela - e gás natural). Os outros $13 \%$ são oriundos de empresas privadas e outras fontes alternativas (MARTINEZ, 2003). As fontes de geração hidroelétrica e termoelétricas estão sob controle estatal por meio da CFE.

A política energética do governo mexicano atual tem preferido priorizar a importação de energia dos Estados Unidos em lugar de investir na cons- 
trução de novas plantas nas regiões de fronteira com esse país (ALONSO, 2003).

No que se refere à totalidade do Sistema Elétrico Nacional (SEM) no México, a predominância do Estado é grande: este detém aproximadamente $87 \%$ do total da capacidade instalada, que, além do parque gerador de energia, conta com uma ampla rede de transmissão e distribuição, interconectadas nacionalmente. Ainda conta com o sistema dos EUA e Belize (sistemas isolados que se encontram na Península da Baixa Califórnia, sendo que um deles está interconectado com a rede elétrica dos EUA) (ARGENTINA, 2009). Os outros $13 \%$ são provenientes da autoprodução e da co-geração de agentes privados e públicos que compõem o Sistema Interconectado Nacional (SIN).

A predominância estatal no setor elétrico apresenta-se sob a forma de um duopólio público integrado verticalmente. As duas empresas públicas são, respectivamente, a Comisión Federal de Electricidad (CFE), que responde por aproximadamente por $82,5 \%$ do total da geração e distribuição nacional, e a também estatal Luz y Fuerza Del Centro (LFC), que é responsável por aproximadamente 5\% da geração e distribuição para a área central do país, com o devido destaque da Cidade do México. Os 13\% restantes para cobertura total do país ficam sob a responsabilidade de autoprodutores e da co-geração de agentes privados e públicos que, vistos de forma isolada, respondem por uma parcela muito pequena da produção e distribuição de eletricidade no país.

Além das estatais que controlam o setor elétrico mexicano, a partir de 1993 foi criada a Comisión Reguladora de Energia (CRE) com a proposição de ser um órgão técnico ligado à Secretária de Energia. Em 1995, esse ente regulador acabou por assumir as funções regulatórias anteriormente de competência da Secretaria de Energia. As atribuições da CRE são as seguintes:

a) outorgar permissões e aprovar os contratos do setor;

b) solucionar controvérsias entre os agentes setoriais;

c) aprovar a metodologia de preços da eletricidade importada pela CFE e os encargos pelos serviços de transmissão; d) participar da política tarifária, bem como de sua modicidade;

e) editar as resoluções setoriais.

Atualmente o setor elétrico mexicano conta com uma capacidade instalada total de aproximadamente 45,6 GW (45 600 MW). Divide-se entre as empresas Comisión Federal de Electricidad (CFE) e também a estatal Luz y Fuerza del Centro (LFC), sendo 31 073,8 MW de origem termoelétrica (67,72\%); 9 600,1 MW de hidroeletricidade (21,15\%); 2600 MW de carboeletricidade (5,87\%); 1 364,9 MW de nucleoletricidade (3,08\%); 959 MW de geotermoeletricidade (2,17\%) e 2,2 MW de eólica $(0,01 \%)^{23}$.

Da capacidade total instalada no México, 44 269,74 MW são oriundas da CFE, donde 9 363,82 MW são de hidroelétricas; 29 979,36 MW correspondem às termoelétricas que consomem hidrocarboneto; 2600 MW são carboelétricas; 959,5 MW geotermoelétricas; 1 364,88 MW são nucleoelétricas; e 2,18 MW provenientes de energia eólica. Já a LFC responde por aproximadamente $1330,26 \mathrm{MW}$, donde 26,9\% são de origem termoelétrica, $28,3 \%$ de hidroeletricidade e $44,8 \%$ de turbogas.

Como evidenciado nesta apresentação do setor elétrico mexicano, o Estado ainda mantém hegemonia na atuação no setor, seja na geração/ produção, na transmissão ou na distribuição, embora as pressões para a liberalização do setor não faltem.

Nesse sentido, reforça-se a necessidade de terse no Estado o principal ator responsável para garantir a construção, ampliação, renovação, modernização, expansão e manutenção da infra-estrutura elétrica do país.

Embora o México, assim como grande parte dos países latino-americanos, tenha implementado políticas econômicas orientadas para o mercado durante a década de 1990, privatizando inúmeras empresas e setores estatais (em nível federal e estadual), no setor elétrico mexicano houve pouco avanço das privatizações. O setor permaneceu

23 As fontes para os dados utilizados aqui são: Comisión Federal de Electricidad (2009), Comisión Reguladora de Energía (2009) e Luz y Fuerza del Centro (2009). 
majoritariamente nas mãos do Estado, ficando para o capital privado (nacional e internacional) apenas uma parcela pequena da autoprodução e co-geração.

O caso mexicano difere do caso argentino, que privatizou o setor elétrico de forma rápida, profunda e intensa, e do caso brasileiro, que privatizou de forma mais lenta e desigual o equivalente a $80 \%$ da distribuição e $20 \%$ da geração de energia elétrica (o que significa uma grande proporção de empresas privatizadas). No México, o setor elétrico passou pela década de 1990 sem grandes alterações significativas, ou seja, as grandes empresas estatais continuaram estatais e o capital privado (nacional e internacional) teve de contentar-se com pequenas participações na autoprodução e na cogeração de energia elétrica.

A ação político-institucional do estado mexicano foi fundamental para o desenvolvimento do setor elétrico. Como o setor apresenta algumas especificidades com relação a outros ramos industriais, tais como o planejamento e a capacidade de investimento com longo prazo de maturação, torna-se fundamental a presença pró-ativa do Estado no setor elétrico. Primeiro porque o setor elétrico é intensivo em capital e necessita de grandes investimentos financeiros. Em segundo lugar porque o tempo de maturação dos empreendimentos elétricos é de longo prazo, precisando tanto de estudos técnicos, econômicos, comerciais, ambientais e sociais. Em terceiro lugar, porque as instalações das indústrias elétricas mexicanas, principalmente referentes às hidroelétricas, não podem ser vendidas facilmente no mercado como sucede com a maquinaria da maioria das indústrias de transformação (ARAGÓN, 2003). Por fim, o setor elétrico tem que entregar o produto final aos consumidores no momento exato, sem interrupções ou atrasos e na quantidade devida, isso porque a energia elétrica não pode ser armazenada em quantidades significativas.

Somadas a tais questões técnicas e econômicas, há as constantes disputas e conflitos entre os diversos atores sociais e políticos envolvidos direta ou indiretamente no setor elétrico mexicano, que terminaram por bloquear as privatizações no setor elétrico deste país.

\section{CONCLUSÕES}

Como exposto até aqui, as orientações das políticas liberalizantes para o mercado no setor elétrico, seja no Brasil, Argentina ou México, seguem algumas similaridades, embora ocorridas em tempos diferentes seguindo as particularidades dos embates de forças políticas e sociais no âmbito nacional de cada país.

Outra diferença entre os países acima referidos é o tipo predominante de fonte para a geração de energia elétrica. Ao passo que no Brasil a principal fonte é a hidroeletricidade, na Argentina e no México é a termoeletricidade

No México, as privatizações do setor elétrico avançaram muito pouco em função dos fatores expostos acima. Na Argentina, o setor foi passado a empresas privadas (nacionais e internacionais) de forma rápida e intensa já na primeira metade da década de 1990. Já no Brasil, as privatizações centraram-se no setor de distribuição de energia elétrica: empresas privadas passaram a dominar aproximadamente $80 \%$ do parque distribuidor de energia brasileiro, enquanto que a geração foi privatizada em apenas $20 \%$.

O Brasil, a Argentina e o México tiveram movimentos semelhantes quanto à organização e institucionalização do setor elétrico. Nesses três países, o setor elétrico começa a estruturar-se a partir do capital privado (em grande maioria internacional). Desde a década de 1930, principalmente depois da II Guerra Mundial, há uma gradativa incorporação do setor por parte do Estado, que se torna o principal investidor na geração de energia. Por fim, a partir das crises do petróleo na década de 1970 e das sucessivas crises da década de 1980, políticas energéticas de orientação neoliberal nos três países trazem parcela do setor de volta às empresas privadas (nacionais e internacionais).

A sincronia das privatizações nos três países, contudo, variou de acordo com as coalizões de apoio e de veto. Na Argentina, as privatizações no setor elétrico deram-se de forma rápida, intensa e concentrada no tempo. Isso se explica em parte pela grave crise em que o país encontrava-se. No Brasil, além da reforma do setor de eletricidade ser mais lenta, vários obstáculos, entre eles, as dificuldades em dividir as grandes empresas geradoras de eletricidade (Chesf e Furnas, por exemplo) em mais de uma unidade (empresa) impediram o avanço do processo de privatização, que com a deflagração da crise, em 2001, é interrompido de vez. O México avançou muito pouco nas privatizações do setor elétrico em grande medida porque a institucionalidade criada na década de 
1940, que garantia a exclusividade do Estado no setor, não foi modificada, atuando como obstáculo às reformas setoriais.

Por outro lado, a Argentina e o Brasil, que realizaram um processo de privatização setorial mais forte, apresentaram crise no setor: a crise argentina em 2001 e 2003 e o “apagão” brasileiro de 2001.

Por fim, as reformas orientadas para o mercado foram resultado de fatores exógenos e endógenos (que, dependendo das configurações de forças presentes, acabam por influenciar os governos para um padrão específico de estratégia para o desenvolvimento). Ou seja, não há unicidade histórica para escolhas de estratégias, mas sim composição de estratégias de desenvolvimento decorrentes do embate entre as diversas forças políticas presentes e atuantes num determinado espaço (Estado) com suas variantes nacionais e internacionais.

Alessandro André Leme (lemeaa@gmail.com) é Doutor em Ciência Política pela Universidade Estadual de Campinas (UNICAMP).

\section{REFERÊNCIAS BIBLIOGRÁFICAS}

ABRUCiO, F. L. \& COSTA, V. M. F. 1999. Reforma do Estado e o Contexto Federativo Brasileiro. Pesquisas, São Paulo, n. 12.

ALMEIDA, M. H. T. \& MOYA, M. 1997. A reforma negociada: o Congresso e a política de privatização. Revista Brasileira de Ciências Sociais, São Paulo, v. 12, n. 34. Disponível em : $<$ http://www.anpocs.org.br/portal/ publicacoes/rbcs_00_34/rbcs34_07.htm>. Acesso em : 20.abr.2009.

ALMEIDA, M. H. T. 1999. Negociando a Reforma: A Privatização de Empresas Públicas no Brasil. ENCONTRO ANUAL DA ASSOCIAÇÃO NACIONAL DE PÓS-GRADUAÇÃO E PESQUISA EM CIÊNCIAS SOCIAIS, 22, Caxambu. Anais... Caxambu : Anpocs.

ALONSO, M. L. F. 2003. Reforma del Estado y reforma administrativa. México : Centro de Estúdios Sociales y de Opinión Pública.

ARAGÓN, L. C. 2003. El modelo britânico em la industria eléctrica mexicana. México : Siglo XXI.

ARBIX, G. 2002. Da liberalização cega dos anos 90 à construção estratégica do desenvolvimento. Tempo Social, São Paulo, v. 14, n. 1, p. 117, maio. Disponível em : <http:// www.scielo.br/pdf/ts/v14n1/v14n01a01.pdf>. Acesso em : 19.abr.2009.

AYERBE, L. F. 1998. Neoliberalismo e política externa na América latina. São Paulo : Unesp.

AZPIAZU, D. (org.). 2002. Privatizaciones y poder económico: la consolidación de una sociedad excluyente. Buenos Aires : Universidad Nacional de Quilmes.

AZPIAZU, D. \& BASUALDO, E. (orgs.). 2002. El proceso de privatización en argentina: la renegociación con las empresas privatizadas. Buenos Aires : Universidad Nacional de Quilmes-Página/12.

AZPIAZU, D. \& SCHORR, M. 2001. Desempeño reciente y estructura Del mercado gasífero argentino: asimetrías tarifarias, ganancias extraordinarias y concentración del capital. Segunda Serie de Documentos de Informes de Investigación, Flacso, Buenos Aires, n. 1, dic. Disponível em : <http:// bibliotecavirtual.clacso.org.ar/ar/libros/argentina/flacso/no4_MercadoGasiferoDIC01.pdf>. Acesso em : 19.abr.2009.

2003. Crónica de una sumisión anuncia$d a$ : las renegociaciones con las empresas privatizadas bajo la administración Duhalde. Buenos Aires : Siglo XXI.

BASUALDO, E. 2002. Sistema político y modelo de acumulación en la argentina. Buenos Aires : Universidad Nacional de Quilmes.

BATISTA, P. N. 1994. O Consenso de Washington: a visão neoliberal dos problemas latinoamericanos. In : BARBOSA, L. S. \& CARDOSO, F. H. Em defesa do interesse nacional. Rio de Janeiro : Paz e Terra.

BERMANN, C. 2002. Energia no Brasil: para que? Para quem? Crise e alternativas para um país sustentável. São Paulo : Livraria da Física. 
BIELSCHOWSKY, R. 1999. Investimentos na indústria brasileira depois da abertura e do real: o mini-ciclo de modernizações, 1995-1997. Série Reformas Econômicas, Cepal, n. 44, nov. Disponível em : < http:// www.rrojasdatabank.info/eclacsa/ lcl1289.pdf>. Acesso em : 19.abr.2009.

BIONDI, A. 1999. O Brasil privatizado: um balanço do desmonte do Estado. São Paulo: Fundação Perseu Abramo.

CALABI, A. S.; FONSECA, E. G.; SAES, F. A. M.; KINDI, E.; LIMA, J. L.; LEME, M. I. P. \& REICHSTUL, H-P. 1983. A Energia e a Economia Brasileira. São Paulo : Pioneira.

CANO, W. 1988. A interiorização do desenvolvimento econômico no interior paulista. Col. “Economia paulista”, v. 1. São Paulo : Fundação Sistema Estadual de Análise de Dados.

1995. Reflexões sobre o Brasil e a nova (des)ordem internacional. Campinas : Unicamp.

2000. Soberania e política econômica na América Latina. São Paulo : Unesp.

CYSNE，R. P. 2000. Aspectos macro e microeconômicos das reformas brasileira. Reformas Econômicas, Cepal, Santiago, n. 63, p. 1-71, maio. Disponível em : <http:// www.eclac.org/publicaciones/xml/5/4585/ lcl1359p.pdf $>$. Acesso em : 19.abr.2009.

DINIZ, E. 1997. Crise, reforma do estado e governabilidade. Rio de Janeiro : FGV.

DONAHUE, J. D. 1992. Privatização - fins públicos, meios privados. Rio de Janeiro : J. Zahar.

EASTERLY, W. \& SERVÉN, L. 2003. The Limits of Stabilization : Infrastructure, Public Deficits and Growth in Latin America. Stanford : Stanford University-World Bank.

EDWARDS, S. 1995. Crisis and Reform in Latin America: From Despair to Hope. Oxford, U. K. : Oxford University-World Bank.

ELETROPAULO. 1997. História \& Energia 7: Estatização x Privatização. Departamento de Patrimônio Histórico. São Paulo : Eletropaulo.

FARIAS NETO, P. S. 1994. Gestão Efetiva e Privatização: uma perspectiva brasileira. Rio de Janeiro : Qualitymark.
FERNANDES, F. 1981. Capitalismo dependente e classes sociais na América Latina. Rio de Janeiro : J. Zahar.

FERREIRA, C. K. L. 2000. Privatização do setor elétrico no Brasil. In : PINHEIRO, A. C. \& FUKASAKU, K. (eds.). A Privatização no Brasil: o caso dos serviços de utilidade pública. Rio de Janeiro : Banco Nacional de Desenvolvimento Econômico e Social.

FIORI, J. L. 1995. Em busca do dissenso perdido: ensaios críticos sobre a festejada crise do Estado. Rio de Janeiro : Insight.

FURTADO, C. 1992. Brasil - a construção interrompida. Rio de Janeiro : Paz e Terra.

GUZMÁN, F. J. C. 1994. La modernización de la empresa pública en México: logros y resultados 1988-1994. Ciudad del México : Fondo de Cultura Econômica.

HARVEY, D. 2004. O novo imperialismo. São Paulo : Loyola.

JANNUZZI, G. M. 1996. A política energética e o meio ambiente: instrumentos de mercado e regulação. In : ROMEIRO, A. R.; RYDON, B. P. \& LEONERDI, M. L. A. (orgs.). Economia do Meio Ambiente: teoria, políticas e gestão de espaços regionais. Campinas : Unicamp.

LEITE, A. D. 1995. A Energia do Brasil. Editora. Rio de Janeiro : Nova Fronteira.

LEME, A. A. 2000. O impacto da privatização da Cesp sobre o processo de implantação de uma nova obra da concessionária: uma abordagem sociológica acerca do caso de Santa Maria da Serra/SP. São Carlos. Monografia (Graduação em Ciências Sociais). Universidade Federal de São Carlos.

2005. Globalização e Reformas Liberalizantes: contradições na reestruturação do setor elétrico brasileiro nos anos 90. Revista Sociologia e Política, Curitiba, n. 25, p. 165-186. Disponível em : <http://www.scielo.br/pdf/ rsocp/n25/31118.pdf>. Acesso em : 19.abr.2009.

LONGO, R. \& BREMANN, C. 2002. Avaliação do processo de reestruturação do setor elétrico brasileiro: das propostas à realidade. In : $\mathrm{CON}-$ GRESSO BRASILEIRO DE ENERGIA: IV SEMINÁRIO LATINO-AMERICANO DE ENERGIA, 9, Rio de Janeiro. Anais... Rio de Janeiro : Coppe-UFRJ. 
MACIEL, C. S. 1997. Globalização, crise do padrão de financiamento da economia $e$ reestruturação institucional do setor elétrico brasileiro. Campinas. Tese (Doutorado em Economia). Universidade Estadual de Campinas.

MARTIN, J. M. 1992. A Economia Mundial da Energia. São Paulo : Unesp.

MARTÍNEZ, I. 2003. México: desarrollo y fortalecimiento del sector estratégico de energia eléctrica. Ciudad del México : Siglo XXI.

MEDEIROS, A. R. 1996. O capital privado na reestruturação do setor elétrico brasileiro. In : ELETROPAULO. História \& Energia. Departamento de Patrimônio Histórico da Eletropaulo. São Paulo : Eletropaulo.

MEIRELES, S. 1999. Setor elétrico em choque. Cadernos do Terceiro Mundo, Rio de Janeiro, n. 212, set.

MELLO, M. F. 1992. A privatização no Brasil: análise dos seus fundamentos e experiências internacionais. São Paulo. Tese (Doutorado em Economia). Universidade de São Paulo.

MIELNIK, O. \& NEVES, C. C. 1988. Características da estrutura de produção de energia hidroelétrica no Brasil. In : ROSA, L. P.; SIGAUD, L. \& MIELNIK, O. (coords.). Impactos de grandes projetos hidrelétricos e nucleares. São Paulo : Marco Zero-CNPq.

MOREIRA, A. R. B.; DAVID, P. A. M-S. \& ROCHA, K. 2003. Regulação do preço da energia elétrica e viabilidade do investimento em geração no Brasil. IPEA, Rio de Janeiro, Texto para Discussão n. 978, ago. Disponível em : <http://www.cipedya.com/web/ FileDownload.aspx? IDFile $=101226>$. Acesso em : 19.abr.2009.

MOREIRA, A. R. B.; MOTTA, R. S. \& ROCHA, K. 2003. A expansão do setor brasileiro de energia elétrica: falta de mercado ou de planejamento. IPEA, Rio de Janeiro, Notas Técnicas, set.

NUNES, E. 2001. O quarto poder: gênese, contexto, perspectivas e controle das agencias reguladoras. In : SEMINÁRIO INTERNACIONAL SOBRE AGÊNCIAS REGULADORAS DE SERVIÇOS PÚBLICOS, 2, Brasília. Brasília : Instituto Hélio Beltrão, set. Disponível em : <http://www.ancine.gov.br/media/
LEITURAS/QUARTO_PODER.pdf>. Acesso em : 19.abr.2009.

ORTIZ, R. \& SCHORR, M. 2002. La reconfiguración del poder económico en el sector de los hidrocarburos durante la década del noventa y sus consecuencias en la salida de la convertibilidad. In : JORNADAS DE SOCIOLOGÍA, 5, nov., Buenos Aires. Buenos Aires : Universidad de Buenos Aires.

PASCOTTO, S. 2001. Anamnésia da crise do setor elétrico. Jornal dos economistas, Rio de Janeiro, n. 144, p. 5-6, jun. Disponível em : <http:/ / w w w. core c on - r j . org.br/pdf/ aje_jun2001.pdf $>$. Acesso em : 20.abr.2009.

PETRAS, J. 1999. Armadilha neoliberal e alternativas para a América Latina. São Paulo : Xamã.

PINHEIRO, A. C. 2000. A experiência brasileira de privatização: o que vem a seguir? IPEABndes, Rio de Janeiro, Texto para discussão n. 87, nov. Disponível em : <http:// www.bndes.gov.br/conhecimento/td/Td87.pdf $>$. Acesso em : 20.abr.2009.

2003. Uma agenda pós-liberal de desenvolvimento para o Brasil. IPEA, Texto para discussão n. 989, out. Disponível em : < http:/ / p a p e r s.s s r . c o m/s ol 3/ papers.cfm?abstract_id $=482821>$. Acesso em : 20.abr.2009.

PINHEIRO, A. C. \& GIAMBIAGI, F. 2000. Os antecedentes macroeconômicos e a estrutura institucional da privatização no Brasil. In : PINHEIRO, A. C. \& FUKASAKU, K. (eds.). A Privatização no Brasil - o caso dos serviços de utilidade pública. Brasília : Banco Nacional de Desenvolvimento Econômico e Social.

PIRES, J. C. L. 1999. Políticas regulatórias no setor de energia elétrica: a experiência dos Estados Unidos e da União Européia. Rio de Janeiro : Banco Nacional de Desenvolvimento Econômico e Social.

REVUELTAS, A. 1993. Las Reformas Del Estado en México: Del Estado benefactor AL Estado neoliberal. Política y Cultura, Ciudad del Mexico, n. 3, invierno. Disponível em : <http:/ /redalyc.uaemex.mx/redalyc/src/inicio/ ArtPdfRed.jsp?iCve=26700314>. Acesso em : 29.abr.2009. 
REZENDE, F. \& PAULA, T. B. (coords.). 1997. Infra-Estrutura: perspectiva de reorganização; setor elétrico. Brasília : IPEA.

ROMERO, L. A. 2003. La crisis Argentina: uma mirada al siglo XX. Buenos Aires : Siglo XXI.

ROSA, L. P. 1997. Energia no Brasil e no Reino Unido: possibilidades de cooperação. Trabalho apresentado no Instituto de Pesquisa de Relações Internacionais, Brasília, set. Brasília : Ministério das Relações Exteriores. Disponível em : <http://www.ivig.coppe.ufrj.br/ docs/inglater.pdf $>$. Acesso em : 19.abr.2009.

2002. A crise de energia elétrica: causas e medidas de mitigação. In : BRANCO, A. M. (org.). Política energética e crise de desenvolvimento. São Paulo : Paz e Terra.

ROSA, L. P.; TOLMASQUIM, M. T. \& PIRES, J. C. L. 1998. A reforma do setor elétrico no Brasil e no mundo: uma visão crítica. Rio de Janeiro : Relume Dumará.

SALGADO, L. H. 2003. Agências regulatórias na experiência brasileira: um panorama do atual desenho institucional. IPEA, Rio de Janeiro, Texto para Discussão n. 941, mar. Disponível em : <http://www.cipedya.com/web/ FileDetails.aspx ?IDFile $=101188>$. Acesso em : 20.abr.2009.

SALLUM JR., B. 2003. Metamorfoses do Estado Brasileiro no final do século XX. Revista Brasileira de Ciências Sociais, São Paulo, v. 18, n. 52, jun. Disponível em : <http:// www.scielo.br/pdf/rbcsoc/v18n52/ 18065.pdf $>$. Acesso em : 20.abr.2009.
SAUER, I. L. 2002. Energia elétrica no Brasil contemporâneo: a reestruturação do setor, questões e alternativas. In : BRANCO, A. M. (org.). Política energética e crise de desenvolvimento. São Paulo : Paz e Terra.

SAUER, I. L.; ROSA, L. P.; D'ARAUJO, R. P.; CARVALHO, J. F. \& TERRY, L. A. 2003. A reconstrução do setor elétrico brasileiro. São Paulo : Paz e Terra.

SOUZA JR., J. A. 1996. Globalização, indústria de eletricidade e desenvolvimento sustentável. In : ROMEIRO, A. R.; RYDON, B. P. \& LEONERDI, M. L. A. Economia do Meio Ambiente: teoria, políticas e a gestão de espaços regionais. Campinas : Unicamp.

TOLMASQUIM, M. T. \& CAMPOS, A. F. 2002. A reforma do setor elétrico em perspectiva. In : CONGRESSO BRASILEIRO DE ENERGIA, 9, Rio de Janeiro. Anais.... Rio de Janeiro : COPPE/UFRJ, v. 1, p. 454-459.

TORRE, J. C. 1998. El proceso político de las reformas económicas en américa latina. Buenos Aires : Piados SAICF.

VELASCO E CRUZ, S. C. 1998. Alguns argumentos sobre reformas para o mercado. Lua Nova, São Paulo, n. 45.

VELASCO JR., L. 1997. A economia das política públicas: fatores que favoreceram as privatizações no período 1985-1994. Rio de Janeiro : Banco Nacional de Desenvolvimento Econômico e Social.

\section{OUTRAS FONTES}

ARgentinA. Ministerio de Economía y FinanzasS Públicas. 2002. Informe Del sector electrico, año 2001 (provisorio). Buenos Aires : Ministerio de Economía y Finanzas Públicas, nov.

ARGENTINA. Secretaria de Energia. 2002. Impuestos y subsídios sobre lãs tarifas eléctricas a usuário final. Buenos Aires : Secretaria de Energia, abr. Disponível em : <http:/ /energia3.mecon.gov.ar/contenidos/ verpagina.php?idpagina $=2317>$. Acesso em : 20.abr.2009.
. 2002. Impuestos sobre las tarifas eléctricas a usuario final de cooperativas eléctricas de Buenos Aires. Buenos Aires : Secretaria de Energia, jun. Disponível em : <http:// energia.mecon.gov.ar/Publicaciones/ Informe\%20de\%20Impuestos\%20Coop \%20v1.pdf $>$. Acesso em : 20.abr.2009.

BRASIL. Banco Nacional de Desenvolvimento Econômico e Social. 1997. Programa Nacional de Desestatização. Relatório de Atividades. Rio de Janeiro : Banco Nacional de Desenvolvimento Econômico e Social. 
BRASIL. Agência Nacional de Energia Elétrica. 2001. A ANEEL na reestrutura-ção do setor elétrico brasileiro. Brasília : Agência Nacional de Energia Elétrica.

BRASIL. Ministério de Minas e Energia. 2003. $O$ novo modelo do setor elétrico. Brasília : Ministério de Minas e Energia, set.

CEPAL. 2002. Globalización y desarrollo. Santiago : Organización de las Naciones Unidas.

COMISIÓN FEDERAL DE ELECTRICIDAD. 2009. Sítio de internet da Comissão Federal de Eletricidade do México. Disponível em : $<$ http://www.cfe.gob.mx/es/>. Acesso em : 28.abr.2009.

COMISIÓN REGULADORA DE ENERGÍA. 2009. Sítio de internet da Comissão Reguladora de Energia do México. Disponível em :
$<$ http://www.cre.gob.mx/>. Acesso em : 29.abr.2009.

INTERNATIONAL ENERGY AGENCY. 1999. Oil Price Changes and the Macroeconomy: A Brief Overview. Disponível em : <http:// www.iea.org/textbase/nppdf/free/1990/ weo1999.pdf $>$. Acesso em : 19.abr.2009.

LUZ Y FUERZA DEL CENTRO. 2009. Sítio de internet da companhia elétrica mexicana LFC. Disponível em : <http://www.lfc.gob.mx/>. Acesso em : 29.abr.2009.

ORGANIZATION FOR ECONOMIC COOPERATIONAND DEVELOPMENT. 1999. Key World Energy Statisics - from the IEA. Disponível em : <http://www.oecd.org/ document/10/0,3343, en_21571361_ 33915056_39154634_1_1_1_1,00.html>. Acesso em : 19.abr.2009. 
REFORM OF THE ELECTRICAL SECTOR IN BRAZIL, ARGENTINA AND MEXICO CONTRASTS AND PERSPECTIVES IN DEBATE

\section{Alessandro André Leme}

The decade of the 1990s was marked by a global movement for State Reform, primarily in developing countries. In this process, guidelines provided by multi-lateral agencies made themselves felt. A set of liberalizing reforms transferred sectors that had previously been in state hands to private ones. Among these sectors, we give particular salience to the case of energy infra-structure. The electrical sector in Brazil, Argentina and Mexico was consolidated after the Second World War and linked primarily to the State. In the decade of the 1990s, in these three countries, the sector underwent privatizing transformations. The background economic and political plan was very similar in both countries, economic and político-institutional particularities notwithstanding. The hyper-inflation crisis of the 1980s and strong pressures coming from multi-lateral organisms for the realization of marketoriented reforms (privatization and flexibilization, among others) led to changes in the electrical sector in both countries. In this paper, we take a historical, structural and strategic approach. We analyze reforms in the Brazilian electrical sector in connection with those that took place in Argentina and Mexico. We conclude defining the major differences and similarities between the liberalizing policies of the electric sector in Brazil, Argentina and México, specifying the major features of these variations, emphasizing the lack of historical uniqueness in strategic choices and the way development strategies emerge from the conflict between the diverse polítical forces that are present and in action within a particular space (the State) with its national and international variations.

KEYWORDS: State reform; market; electrical sector restructuring; privatization. 

MEXIQUE : CONTRASTES ET PERSPECTIVES EN DÉBAT

\section{Alessandro André Leme}

Au cours des années 1990, un mouvement global de réformes d’État ont marqué cette période, surtout dans les pays en développement. Dans ce processus, les orientations des agences multilatérales se sont encore imposées. L'ensemble des réformes à l'esprit libéral a déplacé vers le secteur privé des secteurs jusqu'alors pris en charge par l'État. Parmi ces secteurs, nous soulignons le cas de l'infrastructure énergétique. Le secteur électrique au Brésil, en Argentine et au Mexique s'est consolidé après la Seconde Guerre Mondiale, et il était pour la plupart lié à l’État. Dans les années 1990, dans ces trois pays, ce secteur connait des changements de privatisation. Cela dans un cadre général (sur le plan politico-économique) assez semblable, bien que ces pays aient des particularités économiques et politico-institutionnelles. La crise de l'hyper-inflation dans les années 1990 et les fortes pressions des organismes multilatéraux pour la mise en place de réformes privilégiant le marché (privatisation et flexibilisation, entre autres) ont entraîné des changements dans le secteur électrique de ces pays. Notre point de départ, dans ce travail, c’est une approche historico-structurale et stratégique. Nous 
examinons les réformes dans le secteur électrique brésilien en parallèlle à celles mises en place en Argentine et au Mexique. Nous concluons en définissant les ressemblances et les différences entre les politiques à l'esprit libéral du secteur électrique au Brésil, en Argentine et au Mexique et nous identifions les principaux facteurs de ces variations, en soulignant qu'il n'existe pas d'unité historique concernant les choix de stratégies, mais plutôt une composition de stratégies de développement née de la confrontation entre les diverses forces politiques présentes et agissant dans un espace limité (État) avec ses variations nationales et internationales.

MOTS-CLÉS : réforme de l’État ; marché ; restructuration du secteur électrique ; privatisation. 